\title{
Temporal and regional performance of dual and triple premixes for soybean rust management in Brazil: A meta-analysis update
}

\begin{abstract}
Jhonatan Paulo Barro ${ }^{1} \cdot$ Kaique S. Alves ${ }^{1}$ Cláudia V. Godoy ${ }^{2}$ Alfredo R. Dias ${ }^{3}$ Carlos A. Forcelini ${ }^{4}$ Carlos M. Utiamada ${ }^{5}$ Edson R. de Andrade Junior ${ }^{6} \cdot$ Fernando C. Juliatti $^{7}$ Fernando J. Grigolli ${ }^{8} \cdot$ Heraldo R. Feksa $^{9}$ - Hercules D. Campos ${ }^{10}$ • Ione C.P.V Chaves ${ }^{11} \cdot$ Ivan Pedro A. Júnior ${ }^{12} \cdot$ João Mauricio Trentini Roy ${ }^{13} \cdot J^{\prime}$ José Nunes, Jr. ${ }^{14}$ • Luana Maria de R. Belufi ${ }^{15}$ - Luciana C. Carneiro ${ }^{16}$ • Luís Henrique C. P. da Silva ${ }^{17} \cdot$ Marcelo G. Canteri $^{18} \cdot$ Marcio M. Goussain Júnior ${ }^{19} \cdot$ Marina Senger $^{20} \cdot$ Maurício C. Meyer $^{2} \cdot$ Moab D. Dias $^{21} \cdot$ Mônica A. $^{23}$. Müller $^{12}$ • Mônica C. Martins ${ }^{22}$ • Mônica Paula Debortolii ${ }^{23}$ Nédio Rodrigo Tormen ${ }^{23}$ • Silvânia H. Furlan ${ }^{24}$ • Tiago F. Konageski ${ }^{25} \cdot$ Valtemir J. Carlin ${ }^{26} \cdot$ Wilson S. Venâncio ${ }^{27} \cdot$ Emerson Del Ponte $^{1 *}$
\end{abstract}

Affiliations: 1 Departamento de Fitopatologia, Universidade Federal de Viçosa, Viçosa, MG, 36570-000, Brazil; 2 Embrapa Soja, Londrina, PR, 86001-970, Brazil; 3 Fundação Chapadão,

Chapadão do Sul, MS, 79560-000, Brazil; 4 Universidade de Passo Fundo, Passo Fundo, RS, 99052-900, Brazil; 5 Tagro, Londrina, PR, 86070-460, Brazil; 6 Instituto Mato-Grossense do Algodão, Cuiabá, MT, 78049-015, Brazil; 7 Universidade Federal de Uberlândia, Uberlândia, MG, 38400-902, Brazil;

8 Fundação MS, Maracaju, MS, 79150-000, Brazil; 9 Fundação Agrária de Pesquisa Agropecuária,

Guarapuava, $P R, 85139-400$, Brazil; 10 Universidade de Rio Verde, Rio Verde, GO, 75901-970, Brazil; 11

Santagro, Santa Cruz do Sul, RS, 96820-550, Brazil; 12 Fundação Mato Grosso, Rondonópolis, MT, 78750-000, Brazil; 13 Centro de Pesquisa Agrícola Copacol, Cafelândia, PR, 85415-000, Brazil; 14

Centro Tecnológico para Pesquisas Agropecuárias, Goiânia, GO, 74130-012, Brazil; 15 Fundação Rio Verde, Lucas do Rio Verde, MT, 78455-000, Brazil; 16 Universidade Federal de Goiás, Jataí, GO, 75801-615, Brazil; 17 Agro Carregal, Rio Verde, GO, 75907-454, Brazil; 18 Universidade Estadual de Londrina, Londrina, PR, 86057-970, Brazil; 19 Assist Consultoria e Experimentação Agronômica Ltda, Campo Verde, MT, 78840-000, Brazil; 20 3M Experimentação Agrícola, Ponta Grossa, $P R$, 84046-060, Brazil; 21 Universidade Federal do Tocantins, Gurupi, TO, 77330-000, Brazil; 22 Círculo Verde Assessoria Agronômica e Pesquisa, Luís Eduardo Magalhães, BA, 47850-000, Brazil; 23 Instituto Phytus, Santa Maria, Santa Maria, RS, 97111-970, Brazil;

24 Instituto Biológico, Campinas, SP, 13012-970 Brazil; 25 Rural Técnica Experimentos

Agronômicos Ltda., Querência, MT, 78643-000, Brazil; 26 Agrodinâmica, Tangará da Serra, MT, 78300-000, Brazil; 27 Universidade Estadual de Ponta Grossa, Ponta Grossa, PR, 84010-330, Brazil

${ }^{*}$ Corresponding author: Emerson Del Ponte delponte@ufv.br

Data Availability Statement: The data and R scripts that support the findings of this study are openly available in the Open Science Framework project at osf.io/zjfyg/.

Keywords: Phakopsora pachyrhizi, severity, chemical control, profitability

\section{Abstract}

Soybean rust in Brazil is currently controlled with several commercial premixes composed of demethylation-inhibitors (EPOXiconazole, CYPRoconazole, PROThioconazole, TEBUconazole), quinone-outside inhibitors (AZOXystrobin, TriFLoXystrobin, PYRAclostrobin, PICOxystrobin), and succinate demethylation inhibitors (BENZovindiflupyr, BIXaFen, FLUXapyroxad). We updated results on the performance of eight premixes evaluated in 177 cooperative trials conducted in 46 locations across 10 states during six crop seasons (2015 to 2020). All treatments were sprayed three times starting at R1 or R2. Percent control $(\bar{C}, \%)$, from back-transforming meta-analytic estimates of the log of the ratio ranged from $56.2 \%$ (PICO + CYPR) to 76.8\% (BIXF + TFLX + PROT). Estimates of mean yield difference $(\bar{D}, \mathbf{k g} / \mathrm{ha})$ between fungicide-treated and untreated plots were greatest for BIXF + TFLX + PROT $(1,080)$ followed by PICO + BENZ $(1,010)$, PYRA + EPOX + FLUX (981.5), AZOX + BENZ (910), TFLX + PROT (891), PICO + TEBU (682), TFLX + CYPR (646) and PICO + CYPR (600). Significant declines in both $\bar{C}$ and $\bar{D}$ in a time period as short as four years were detected for AZOX + BENZ (35.3\%; $550 \mathrm{~kg} / \mathrm{ha})$ and PICO + BENZ (15.5\%; $359.8 \mathrm{~kg} / \mathrm{ha})$. Variance in $\bar{D}$ was partially reduced by the inclusion of baseline disease as covariate. In trials where baseline disease was $\geq 70 \%$, yield was $250 \mathrm{~kg} / \mathrm{ha}$ greater compared to low baseline disease. Disease control and yield response were generally better in the Southeast, where the frequency of profitable scenarios was $30 \%$ higher on average than in the Northwest. Results of this meta-analysis are critical to support decisions during planning fungicide programs. 


\section{Introduction}

Soybean rust (SBR), caused by the fungus Phakopsora pachyrhizi Syd. \& P. Syd (Goellner et al. 2010; Li et al. 2010), is one of the most economically important diseases of soybean (Glycine max (L.) Merr.). First reported in Brazil in 2001 (Yorinori et al. 2005), SBR can lead to severe losses in the yield (80 to 90\%) according to literature reports based on experimental research data (Dalla Lana et al. 2015; Godoy et al. 2016a; Delaney et al. 2018).

The overall risk of soybean rust has decreased over the years in Brazil due to the wider adoption of cultural practices that have helped to delay the disease onset including the adoption of early-maturing cultivars, anticipation of sowing dates to allow a second summer crop (corn, cotton or dry-beans), and (law-enforced) adoption of soybean-free period between soybean seasons, which aims to reduce early-season inoculum (Godoy et al. 2016a). To date, major dominant resistance genes have been mapped in at least seven independent loci (Rpp1-Rpp7) on the soybean genome but a limited number of SBR-resistant soybean cultivars is commercially available (Childs et al. 2018). Susceptible and SBR-resistant cultivars have relied on sequential fungicide applications to avoid losses in the presence of the disease (Dalla Lana et al. 2018; Beruski et al. 2020).

In Brazil, demethylation inhibitor (DMI) fungicides were the first to be widely used to control SBR either as a single active ingredient (a.i.) or amended with quinone outside inhibitors (QoI); the most common dual mixture for almost a decade. Following 2013, succinate dehydrogenase inhibitor (SDHI) fungicides have been added to commercial dual mixture formulations, and so triple mixtures have since been incorporated into SBR management (Godoy et al. 2016a). Their recommendations have been based on beneficial results demonstrated by independent academic or industry research, as well as on the annual reports by the national network of cooperative fungicide trials (CFTs) coordinated by the anti-rust consortium (Consórcio Antiferrugem) (Godoy et al. 2016a).

The CFTs for soybean rust have been conducted in Brazil since 2004/05 (Godoy et al. 2016a). These standardized trials have contributed critical knowledge to establishing effective fungicide programs as well to providing information for responding to the emergent issue of fungicide resistance. The after-season summaries are disseminated widely in technical reports (Godoy et al. 2015, 2016b, 2017a, 2018a, 2019, 2020). Their original intent is not to base a 
regional recommendation of fungicide program because sequential sprays of the same fungicide are tested in late season planted crops; the former practice is not encouraged due to fungicide resistance issues (Hollomon 2015). Data from these trials shall serve to define programs of controls considering the sowing date and disease occurrences since trials are also carried out for other soybean pathogens (Edwards-Molina et al. 2018; Barro et al. 2019). In addition, data can be used to compare and monitor fungicide performance over time and space (Dalla Lana et al. 2018).

Continuous surveillance of fungicide efficacy is essential, even more critical when they continue to be used after reports of reduction of efficacy and fungicide resistance have been made available in the country. Temporal and spatial changes, usually a decline in time, but also a recovery, are dependent on which chemical is used and how they are deployed (space and time) and on the capability of the pathogen to adapt and build resistant populations (Hollomon 2015). Indeed, significant temporal declines in the efficacy of control of SBR have been reported after at least four years of fungicide use. These include three single-a.i.: azoxystrobin, cyproconazole, and tebuconazole; and three dual premixes: azoxystrobin + cyproconazole, picoxystrobin + cyproconazole, and pyraclostrobin + epoxiconazole (Dalla Lana et al. 2018). Their poor performances have been linked to the reports of resistance in Brazilian P. pachyrhizi populations to DMI and QoI fungicides (Schmitz et al. 2013; Klosowski et al. 2016). For instance, mutations at the cyp51 gene in pathogenic isolates collected during the 2010 growing season were associated with increased $\mathrm{EC}_{50}$ for epoxiconazole, metconazole, and tebuconazole (Schmitz et al. 2013). Additionally, the occurrence of the F129L substitution, caused by target site mutations at the cytochrome $b$, was linked to a reduction in fungal sensitivity to QoIs (Klosowski et al. 2016). More recently, a mutation in the $\mathrm{SdhC}$ gene, which causes the amino acid substitution $\mathrm{C}-\mathrm{I} 86 \mathrm{~F}$ reducing fungal sensitivity to SDHI fungicides, was detected (Simões et al. 2018).

Whether the triple-mixtures continue to be effective and economic over the years should be best understood by a comprehensive analysis of multiple trials for which independent results show inconsistent results across yearly summaries. Hence, further analyses that combine multiple season data and focus on estimating, not only the means, but the uncertainty and factors explaining variation may provide additional insights into the disease management strategy. 
This meta-analytic approach has become standard in plant pathology to summarize the effect of treatments in plant disease management (Scherm et al. 2009; Machado et al. 2017; Edwards-Molina et al. 2018; Barro et al. 2019) including effect of year in both fungicide efficacy and yield response over time (Dalla Lana et al. 2018).

Therefore, our objectives were to: 1) update on SBR control efficacy and yield response levels to most commonly used fungicides, including triple premixes, evaluated in the past six growing seasons (2014/15 - 2019/20) across all major soybean regions in Brazil; 2) evaluate whether those levels vary over time and among regions; 3) calculate the profitability of fungicides using the meta-analytic estimates of yield response.

\section{Material and Methods}

\section{Data source and criteria for fungicide selection}

Data were obtained from the cooperative fungicide trials (CFTs) coordinated by the anti-rust consortium (Consórcio Antiferrugem) and conducted during the recent six soybean seasons (2014/15 - 2019/20). During this period, 177 independent trials were conducted across 46 locations in 10 Brazilian states (BA, DF, TO, GO, MG, MS, MT, SP, PR, and RS). All data used in this study were published as yearly summaries, where the means of SBR severity (\%) and soybean yield (kg/ha) were statistically compared among all evaluated fungicides within the same year (Godoy et al. 2015, 2016b, 2017a, 2018a, 2019, 2020).

In general, the cooperative trials have been conducted following a standard protocol (same experimental design, a common set of treatments, and a SBR-susceptible cultivar planted in the region). These trials are sown later in the season (Nov to Dec), depending on the region, to ensure they are exposed to increased load of natural inoculum. Briefly, all plots (minimum $5 \mathrm{~m}$ long) were arranged in a randomized complete block design, with four replications. In most trials $(n=112)$, fungicides were applied three times at label rates; while in 65 trials, conducted mainly in 2018/19 $(n=23)$ and 2019/20 ( $n=15)$, four sprays were performed. The first application was made between the R1 (beginning flowering) and R2 (full flowering) growth stages (45-55 days after sowing) with subsequent applications at a 14-day interval. A backpack sprayer pressurized by $\mathrm{CO}_{2}$, which 
was calibrated for a volume of at least 120 liter ha $\mathrm{ha}^{-1}$, was used to perform the fungicide applications. All weed and insect control practices followed regional recommendations.

Disease severity was visually assessed as a percent index for the plot which takes into account percent leaf area exhibiting SBR symptoms, assessed using a standard area diagram (Godoy et al. 2006), in at least 4 points in the plots, and defoliation (100\% is assigned to a defoliated canopy level) between R5 (beginning seed) and R6 (full-seed) growth stages. Yield was obtained by harvesting the central rows (at least $5 \mathrm{~m}^{2}$ ) of each plot after full maturity (R8). Grain weight and moisture were obtained and crop yield was expressed as kilograms/hectare at $13 \%$ moisture.

To be included in the analysis, a fungicide treatment should have been tested in at least 116 trials conducted in at least four years and compared with an untreated check treatment in the same trial. Eight treatments met the criteria, including four DMI + QoI premixes, two QoI + SDHI, and two triple premixes of DMI + QoI + SDHI (Table 1).

Table 1. Fungicide treatments applied for controlling Soybean Rust (SBR) in 177 independent trials from 2014/15 to 2019/20 across 46 locations in ten Brazilian states (BA, DF, TO, GO, MG, MS, MT, SP, PR and RS).

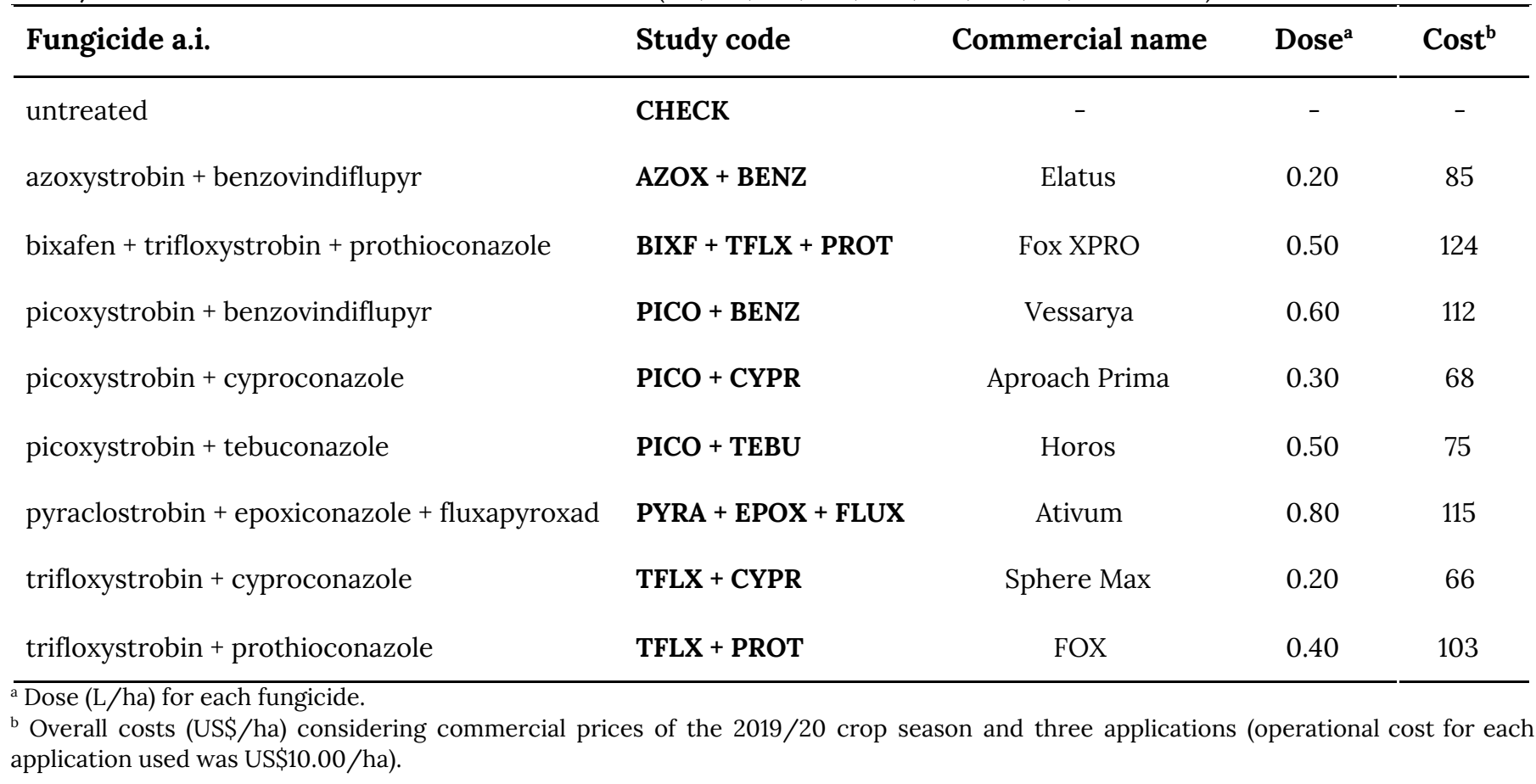


After treatment selection, SBR severity data were available in 177 trials and soybean yield was available for 175 trials. The states were geographically grouped into the Northwestern (NW) region $(n=129$, MT, MS, GO, BA, DF, MG and TO states) and the Southeastern (SE) region ( $n=48, \mathrm{PR}, \mathrm{RS}$ and SP states). MT $(n=61)$, MS $(n=26)$, GO $(n=26)$ together with PR $(n=35)$, were the states with the largest number of trials and accounted $84 \%$ of all trials. Most trials were conducted during 2016/17 $(n=36)$ and 2017/18 $(n=34)$ soybean seasons.

\section{Descriptive analysis}

Box Plots and scatter plots depicting the means of soybean rust severity (\%) and soybean yield ( $\mathrm{kg} / \mathrm{ha})$ (across years and locations) of the untreated and fungicide-treated plots, as well as the means of the same variables in the untreated plots within-region and within-year were used for exploratory analysis. The average (circle) of efficacy $\left(100 *\left[1-\left(\operatorname{Sev}_{\text {Fung }} / \operatorname{Sev}_{\text {Check }}\right)\right]\right)$ across the six most recent seasons, for each fungicide evaluated at each different municipality (latitude and longitude of the centroid) of the 10 Brazilian states was depicted in a map.

\section{Network meta-analysis estimates and inconsistency}

The data were available at the plot level for all treatments for each variable of interest (SBR severity and soybean yield). These were aggregated at the trial level to be used in the meta-analysis (Madden et al. 2016). An arm-based network model, also known as a two-way unconditional linear mixed model, was fitted directly to the treatment means (absolute or log-transformed) to further obtain control efficacy and yield response ( Paul et al. 2008; Machado et al. 2017; Barro et al. 2019). Given the statistical properties of the data (Fig. S1), means of SBR severity were log-transformed, while no transformation was required to obtain the mean absolute difference in yield. The arm-based model can be written as

$$
Y_{i} \sim N\left(\mu, \Sigma+S_{i}\right)
$$

where $Y_{i}$ is the vector of $\mathrm{L}$ (log of the means of SBR severity) or absolute yield for the eight treatments plus the untreated check for the $i$ th study, $\mu$ is a vector representing the mean of $Y_{i}$ across all studies, $\Sigma$ is a $9 \times 9$ between-study 
variance-covariance matrix (for the eight treatments plus the untreated check), and $S_{i}$ is a within-study variance-covariance matrix for the $i$ th study. $N$ indicates a multivariate normal distribution.

Given the availability of data at the plot level, the within-study variability (sampling variance) of $L$ and $D$ was calculated from the mean square error (MSE) obtained from a linear model fitted to each individual trial, as described (Machado et al. 2017). The within-study variability is required to weight studies based on the inverse function of the sampling variance (Paul et al. 2008; 2010). Maximum likelihood estimation models were fitted to the data using the rma.mv function of metafor package (Viechtbauer 2010) of R (R Core Team 2020).

The yield difference $(\bar{D})$ was calculated directly after model fitting by subtracting estimated means of fungicide treatment and untreated check (Madden et al. 2016). For disease severity reduction, estimates of percent control ( $\bar{C}$ ) were calculated by taking the differences of the estimated means of the logs ( $\bar{L}_{S E V}$ ) which equals the ratio of the two means (Paul et al. 2008). The $\bar{C}$ values and their 95\% confidence intervals (CIs) were obtained by back-transforming $\bar{L}_{S E V}$ and the respective upper and lower limits of their 95\% CIs as described in Equation 2.

$$
\bar{C}=\left(1-\exp \left(\bar{L}_{S E V}\right)\right) \times 100
$$

To test for network inconsistency, an important test for multi-arm network meta-analysis (Higgins et al. 2012), we fitted a factorial-type linear model to determine the significance of the treatment $\mathrm{x}$ design interaction, evaluated based on the Wald test statistic. The null hypothesis suggests that the network is consistent (Piepho 2014; Madden et al. 2016). Ten different designs (here design refers to the set of treatments in the trial) were found in the trials reporting both SBR severity and yield response (Table S1).

\section{Analysis of moderator effects}

The network model (Equation 1) was expanded to include both categorical or continuous moderator variables that could explain, at least, a portion of the heterogeneity of the effects across trials (Madden et al. 2016). The expanded model (Paul et al. 2010) is given by 


$$
Y_{i} \sim N\left(\mu+\delta_{i}, \Sigma+S_{i}\right)
$$

where $\delta_{i}$ is the vector representing the moderator variable effect for the $i$ th study and all other terms are as defined previously.

To evaluate whether there was a significant trend of decline in fungicide efficacy and yield response over time, we tested year as a continuous moderator variable. Years 2015 to 2020 were transformed to integers (0 to 6) prior to fitting the model (Dalla Lana et al. 2018). Differences in regression intercept and slopes obtained from the relationships between the years and log severity $\left(\bar{L}_{S E V}\right)$ and, or absolute yield $(\bar{D})$ between each fungicide treatment and the untreated check were used to predict $\bar{L}_{S E V}$ and $\bar{D}$ as well as the upper and lower limits of their 95\% CI (Dalla Lana et al. 2018). Predicted percent control $(\bar{C})$ was obtained by back-transforming $\bar{L}_{S E V}$ and the respective upper and lower limits of their $95 \%$ CIs as explained previously (Equation 2).

With regard to categorical variables, we created a baseline for SBR severity based on the median of the mean values in the untreated check. The SBR severity baseline was divided into two groups, representing low (<70\% SBR severity) and high ( $\geq 70 \%$ SBR severity) disease scenarios. Finally, we created an additional categorical variable based on geographical region where states were grouped into the Northwestern (NW) region (MT, MS, GO, BA, DF, TO, MG) and the Southeastern (SE) region (PR, RS, SP) as mentioned previously.

The moderator variables were included in the model and tested using a Wald-type chi-square test to determine if the moderator variables directly affected the differences in logs of SBR severity and the non-transformed yield values (Paul et al. 2008).

\section{Economic analysis}

We calculated the distribution of profits provided by each fungicide separately for the Northwestern and Southeastern region, according to the respective estimates of yield return. The product of the yield gain $(D, \mathrm{~kg} / \mathrm{ha})$ and the soybean price ( $S_{P}, \mathrm{USS} / \mathrm{kg}$ ) was used to calculate the income ( $I$, USS $\left./ \mathrm{ha}\right)$. The profit of each fungicide-region combination was calculated by subtracting the application costs ( $A_{c}$, USS/ha; fungicide cost + operational cost) from the income. To obtain the 
distribution of profits, we ran 40,000 simulations for each fungicide:region scenarios. The yield gain $(D)$ was assumed normally distributed $D \sim N(\mu, \sigma)$, being $\mu$ the estimated mean yield gain $\bar{D}$ and $\sigma$ the standard error of $\bar{D}[S E(\bar{D})]$. For those fungicides, which a significant decline in yield gain was detected in the meta-regression, we used $\bar{D}$ value corresponding to the more recent year. Soybean price was assumed to be uniformly distributed between US\$0.25/ha and US\$0.35/ha, that is $S_{P} \sim$ Uniform $(0.25,0.35)$, according to the last two seasons (2018/19 to; 2019/2020; AGROLINK 2020). The application costs for each fungicide was also considered uniformly distributed between $5 \%$ above and below the overall cost $x$, that is $A_{c} \sim \operatorname{Uniform}(0.95 x, 1.05 x)$. Overall costs, practised in the 2019/20 crop season, including the operational cost for each application (total of three applications) as US\$10.00/ha, are described in Table 1.

\section{Results}

\section{Data description}

There was a considerable variation in SBR severity and yield in the untreated plots across seasons, regions and locations/trials (each dot in Fig. 1 represents a single trial). Disease severity in the untreated plots of the trials ranged from 6.12 to $100 \%$ (median $72.5 \%$ ). Median of severity was higher (75\%) in the Northeastern than in the Southeastern (69\%) (Fig. 1B). Across growing seasons, the highest (78.9\%) and the lowest (65.2\%) median SBR severities in the untreated check were recorded in the 2015/16 and 2019/20 seasons, respectively (Fig. 1C).

Baseline yield ranged from 541 to $4,848 \mathrm{~kg} / \mathrm{ha}$ (median $=2,501 \mathrm{~kg} / \mathrm{ha}$ ) across the trials. The median of yield was lower in the NW $(2,404 \mathrm{~kg} / \mathrm{ha})$ than in the SE $(2,816 \mathrm{~kg} / \mathrm{ha})$ (Fig. 1E). The greatest median yield $(2,890 \mathrm{~kg} / \mathrm{ha})$ was observed in 2019/20 and the lowest (2,160 kg/ha) in the 2018/19 crop season (Fig. 1F). As expected, decreased SBR severity and increased yield was observed in the fungicide treatments compared with the untreated check (Fig. 1A-D). 

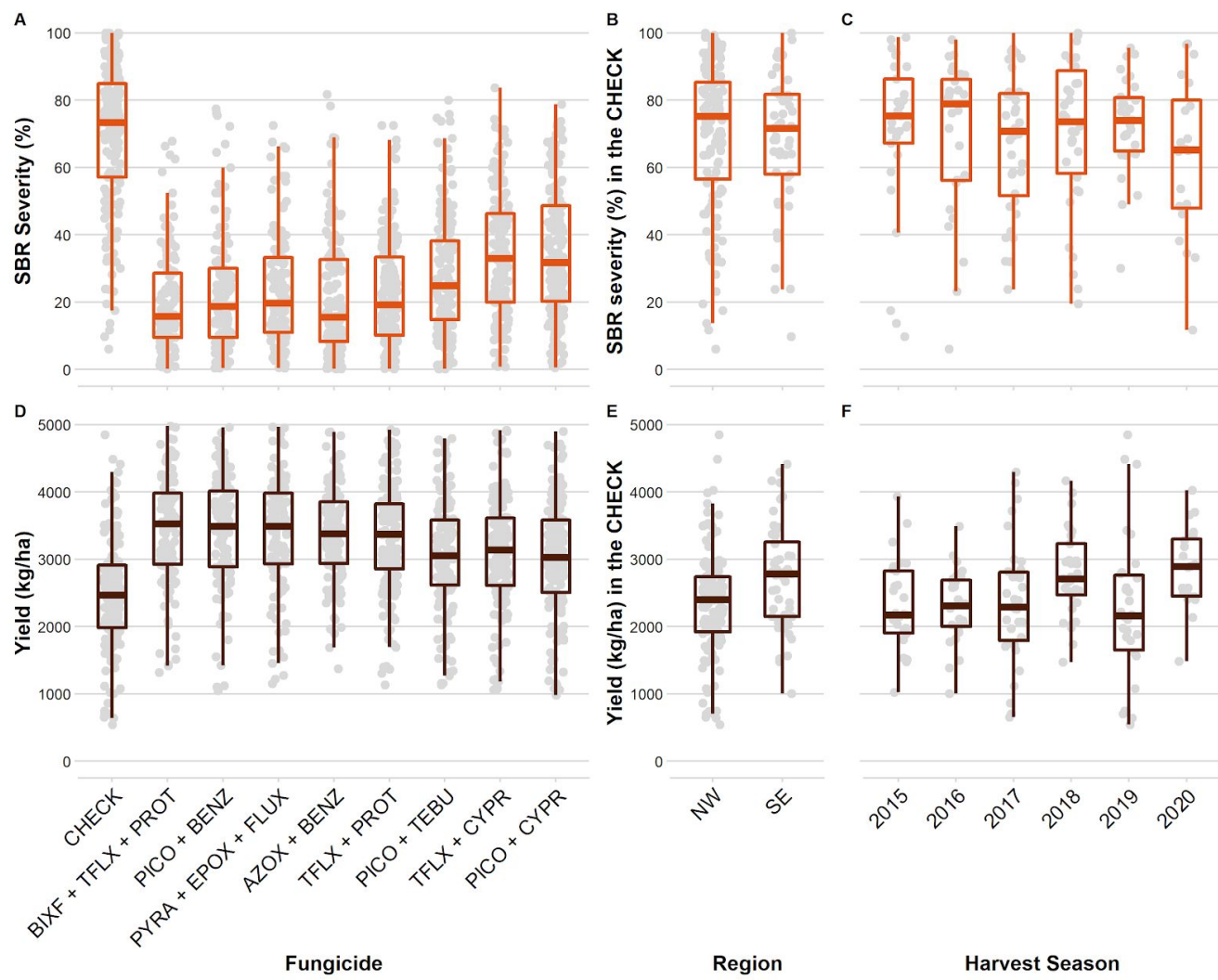

Fig. 1. Box plots depicting the means of soybean rust severity (\%) and soybean yield $(\mathrm{kg}$ ha-1) (across years and locations) of the untreated and fungicide-treated plots (A-D); and the means of the same variables in the untreated plots within-region (B-E) and within-year (C-F) measured from a set of 177 field trials conducted during the last six seasons. Geographic regions defined in our study were: Northwestern (NW) states (MT, MS, GO, BA, DF, TO, MG) and Southeastern (SE) states (PR, RS, SP). The thick horizontal line inside the box represents the median, the limits of the box represent the lower and upper quartiles, and the circles represent yearly means of each treatment (See Table 1 for information on the fungicide treatments).

Average efficacy, for the last six growing seasons, was above $75 \%$ in most locations for AZOX + BENZ, BIXF + TFLX + PROT, PYRA + EPOX + FLUX and TFLX + PROT (Fig. 2). On the other hand, the greatest number of locations with efficacy below $50 \%$ were observed for TFLX + CYPR and PICO + CYPR. The municipality of Erebango (RS, southmost state), where was performed only 1 trial during the $2018 / 19$ crop season, presented the lowest (<25\%) efficacy for five fungicides $(\mathrm{BIXF}+\mathrm{TFLX}+\mathrm{PROT}, \mathrm{PICO}+\mathrm{BENZ}, \mathrm{PICO}+\mathrm{CYPR}, \mathrm{PICO}+\mathrm{TEBU}$ and TFLX + CYPR). In Ponta Grossa (PR; $n=5)$, and Nova Xavantina (MT; $n=1)$ percent control values above $75 \%$ were observed for all the eight fungicide treatments (Table S2;

Fig. 2). 


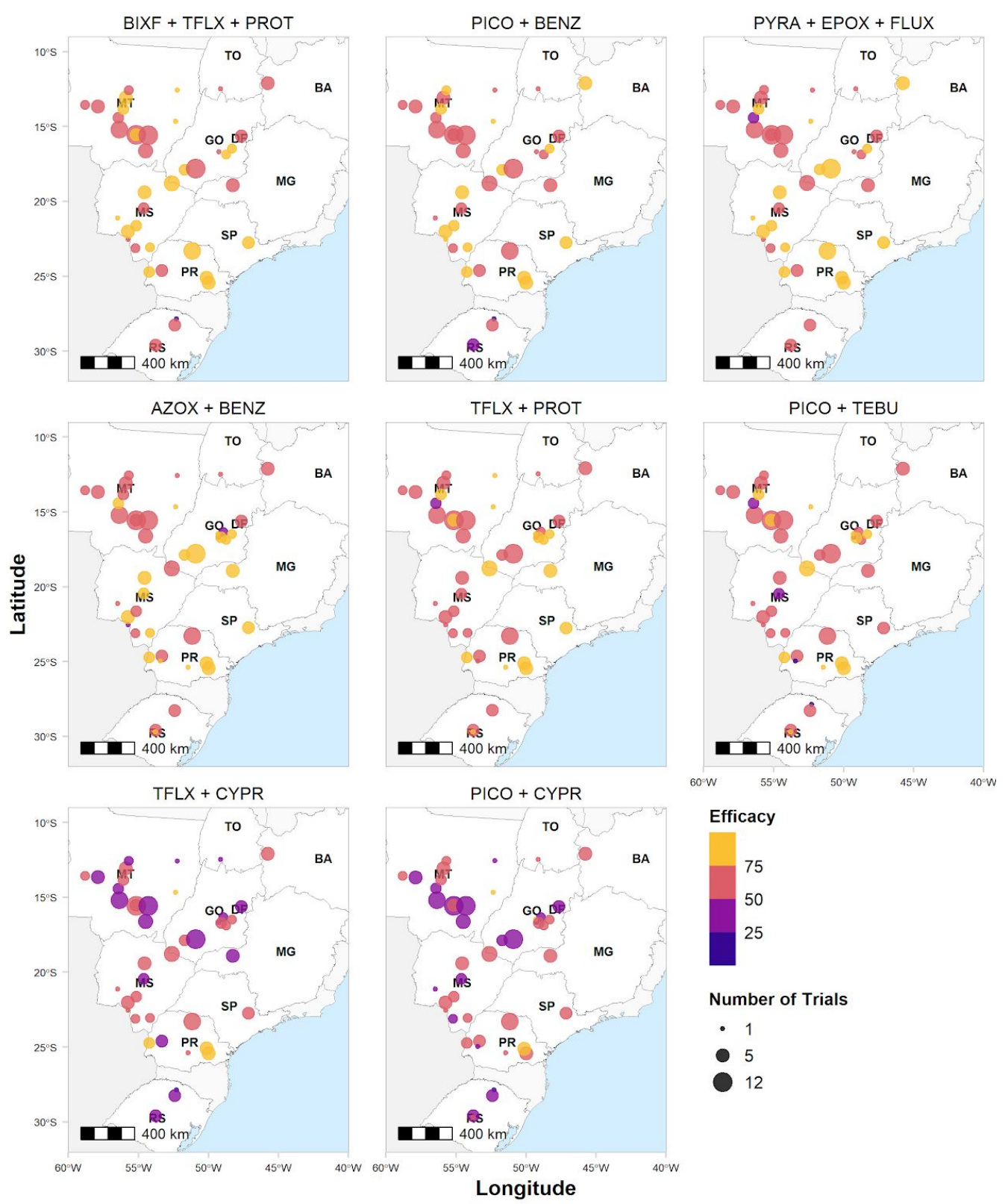

Fig. 2. Geolocation of the 46 municipalities across ten states of Brazil where 177 fungicide evaluation trials were conducted from 2014/15 to 2019/20. Dots represent mean percent efficacy for the eight selected fungicides in each location. The size of the circle is proportional to the number of trials conducted in each location. See Table 1 for complete information of the evaluated fungicides.

\section{Meta-analytic estimates of control efficacy and yield response}

Overall estimates of percent control efficacy $(\bar{C})$, obtained from back-transforming differences of the estimates of log of severity $\left(\bar{L}_{S E V}\right)$ between the fungicide-treated and untreated plots, ranged from 56.2 to $76.8 \%$ across the premixes. Only the triple premix BIXF + TFLX + PROT reduced SBR severity by at 
least $76 \%$ on average. The latter was significantly different $(\mathrm{P}<0.05)$ from PICO + BENZ (74\%), AZOX + BENZ (72.7\%), PYRA + EPOX + FLUX (72.2\%) and TFLX + PROT (71.9\%), all with percent control greater than $70 \%$ and not differing statistically between them $(P>0.11)$. This latter group was followed by PICO + TEBU (66\%), which was different from the two least effective fungicides TFLX + CYPR $(57.8 \% ; P$ $<0.0001)$ and PICO + CYPR (56.2\%; P < 0.0001) (Table 2). The difference in percent control efficacy between the most and least effective fungicide was 20.6 percent points. The Wald test determined that network consistency was significantly affected by the study design $(\mathrm{P}<0.0001)$.

Table 2. Overall means and respective confidence intervals of log response ratio $\left(\bar{L}_{\text {Sev }}\right)$ and calculated percent control ( $\bar{C}$ ) of Soybean Rust (SBR) relative to untreated check provided by eight fungicides evaluated in 177 independent trials conducted across 46 locations in ten Brazilian states (BA, DF, TO, GO, MG, MS, MT, SP, PR and RS) during 6 growing seasons (2015-2020).

\begin{tabular}{|c|c|c|c|c|c|c|c|c|c|c|}
\hline \multirow[b]{2}{*}{ Fungicide $^{\mathrm{a}}$} & \multirow[b]{2}{*}{$n^{b}$} & \multirow[b]{2}{*}{$k^{\mathrm{c}}$} & \multicolumn{5}{|c|}{ Effect Size } & \multicolumn{3}{|c|}{ SBR control (\%) } \\
\hline & & & $\bar{L}_{\mathrm{Sev}}$ & $\mathrm{SE}\left(\bar{L}_{\mathrm{Sev}}\right)$ & $\mathrm{CI}_{\mathrm{L}}^{\mathrm{d}}$ & $\mathrm{CI}_{\mathrm{U}}^{\mathrm{d}}$ & P value & $\bar{C}$ & $\mathrm{CI}_{\mathrm{L}}^{\mathrm{d}}$ & $\mathrm{CI}_{\mathrm{U}}^{\mathrm{d}}$ \\
\hline BIXF + TFLX + PROT & 4 & 115 & -1.4612 & 0.0504 & -1.5601 & -1.3624 & $<0.0001$ & 76.80 & 74.39 & 78.98 \\
\hline PICO + BENZ & 4 & 116 & -1.3482 & 0.0520 & -1.4501 & -1.2463 & $<0.0001$ & 74.02 & 71.24 & 76.54 \\
\hline AZOX + BENZ & 5 & 144 & -1.3017 & 0.0541 & -1.4078 & -1.1956 & $<0.0001$ & 72.79 & 69.74 & 75.53 \\
\hline \multicolumn{11}{|l|}{ PYRA + EPOX + } \\
\hline FLUX & 4 & 115 & -1.2812 & 0.0468 & -1.3730 & -1.1895 & $<0.0001$ & 72.23 & 69.56 & 74.66 \\
\hline TFLX + PROT & 6 & 166 & -1.2719 & 0.0462 & -1.3624 & -1.1814 & $<0.0001$ & 71.96 & 69.31 & 74.39 \\
\hline PICO + TEBU & 5 & 149 & -1.0793 & 0.0418 & -1.1613 & -0.9973 & $<0.0001$ & 66.01 & 63.11 & 68.69 \\
\hline TFLX + CYPR & 5 & 143 & -0.8651 & 0.0375 & -0.9385 & -0.7916 & $<0.0001$ & 57.89 & 54.68 & 60.88 \\
\hline PICO + CYPR & 6 & 169 & -0.8268 & 0.0338 & -0.8932 & -0.7605 & $<0.0001$ & 56.25 & 53.25 & 59.06 \\
\hline
\end{tabular}

a See Table 1 for complete information of the evaluated fungicides;

${ }^{\mathrm{b}}$ Number of crop seasons that each fungicide was evaluated;

${ }^{\mathrm{c}}$ Number of trials that each fungicide was evaluated;

${ }^{d}$ Upper $\left(\mathbf{C I}_{\mathrm{U}}\right)$ and lower $\left(\mathbf{C I}_{\mathrm{L}}\right)$ limits of the $95 \%$ confidence interval around $\bar{L}_{\mathrm{Sev}}$ and $\bar{C}$.

The mean estimates of yield difference $(\bar{D})$ between fungicide-treated and the untreated plots ranged from 600 to $1,080 \mathrm{~kg} / \mathrm{ha}$ among the double and triple premixes. Yield response values as high as above $1,000 \mathrm{~kg} / \mathrm{ha}$ were estimated only for BIXF + TFLX + PROT (1,080 kg/ha) and PICO + BENZ (1,010 $\mathrm{kg} / \mathrm{ha})$, which differed statistically between them $(P=0.0344)$. The latter did not differ statistically from PYRA + EPOX + FLUX $(981.5 \mathrm{~kg} / \mathrm{ha} ; \mathrm{P}=0.2499)$. This latter 
group was followed by AZOX + BENZ (910 kg/ha) and TFLX + PROT (891 kg/ha), both statistically different $(P<0.0001)$ from PICO + TEBU $(682 \mathrm{~kg} / \mathrm{ha})$. The least effective fungicides in protecting yield were TFLX + CYPR (646 kg/ha) and PICO + CYPR $(600 \mathrm{~kg} / \mathrm{ha})$, which were statistically different between them $(\mathrm{P}<0.0001)$ (Table 3). The difference between the higher and lower estimated yield means was $480 \mathrm{~kg} / \mathrm{ha}$. The Wald test for the treatment $\mathrm{x}$ design interaction showed that the network was inconsistent $(\mathrm{P}<0.001)$.

Table 3. Overall means and respective confidence intervals of unstandardized difference in soybean yield $(\bar{D})$ between fungicide-treated and untreated plots for eight selected fungicide treatments evaluated in 177 independent trials conducted across 46 locations in ten Brazilian states (BA, DF, TO, GO, MG, MS, MT, SP, PR and RS) during 6 growing seasons (2015-2020).

Yield response $\left(\mathrm{kg} \mathrm{ha}^{-1}\right)$

\begin{tabular}{|c|c|c|c|c|c|c|c|}
\hline Fungicide $^{a}$ & $n^{b}$ & $k^{\mathrm{c}}$ & $\bar{D}$ & $\mathrm{SE}(\bar{D})$ & $\mathrm{CI}_{\mathrm{L}}^{\mathrm{d}}$ & $\mathrm{CI}_{\mathrm{U}}^{\mathrm{d}}$ & P value \\
\hline BIXF + TFLX + PROT & 4 & 116 & 1080.01 & 40.91 & 999.81 & 1160.20 & $<0.0001$ \\
\hline PICO + BENZ & 4 & 118 & 1010.92 & 38.58 & 935.29 & 1086.55 & $<0.0001$ \\
\hline PYRA + EPOX + FLUX & 4 & 116 & 981.51 & 38.93 & 905.20 & 1057.82 & $<0.0001$ \\
\hline AZOX + BENZ & 5 & 145 & 910.62 & 38.27 & 835.60 & 985.64 & $<0.0001$ \\
\hline TFLX + PROT & 6 & 169 & 891.03 & 32.08 & 828.15 & 953.91 & $<0.0001$ \\
\hline PICO + TEBU & 5 & 154 & 682.11 & 28.97 & 625.32 & 738.89 & $<0.0001$ \\
\hline TFLX + CYPR & 5 & 146 & 646.43 & 25.37 & 596.69 & 696.16 & $<0.0001$ \\
\hline PICO + CYPR & 6 & 175 & 600.39 & 25.26 & 550.86 & 649.91 & $<0.0001$ \\
\hline
\end{tabular}

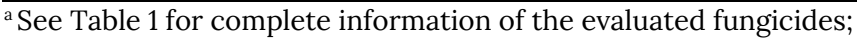

${ }^{\mathrm{b}}$ Number of crop seasons that each fungicide was evaluated;

${ }^{c}$ Number of trials that each fungicide was evaluated;

${ }^{\mathrm{d}} \operatorname{Upper}\left(\mathbf{C I}_{\mathrm{U}}\right)$ and lower $\left(\mathbf{C I}_{\mathrm{L}}\right)$ limits of the $95 \%$ confidence interval around $\bar{D}$.

In general, there was a linear pattern in the relationship between control efficacy and yield difference. As shown previously, the most effective in reducing disease severity and leading to the greatest mean yield response was the triple premix BIXF + TFLX + PROT. Again, the two least effective fungicides in reducing disease severity and protecting yield were TFLX + CYPR and PICO + CYPR (Fig. 3). 


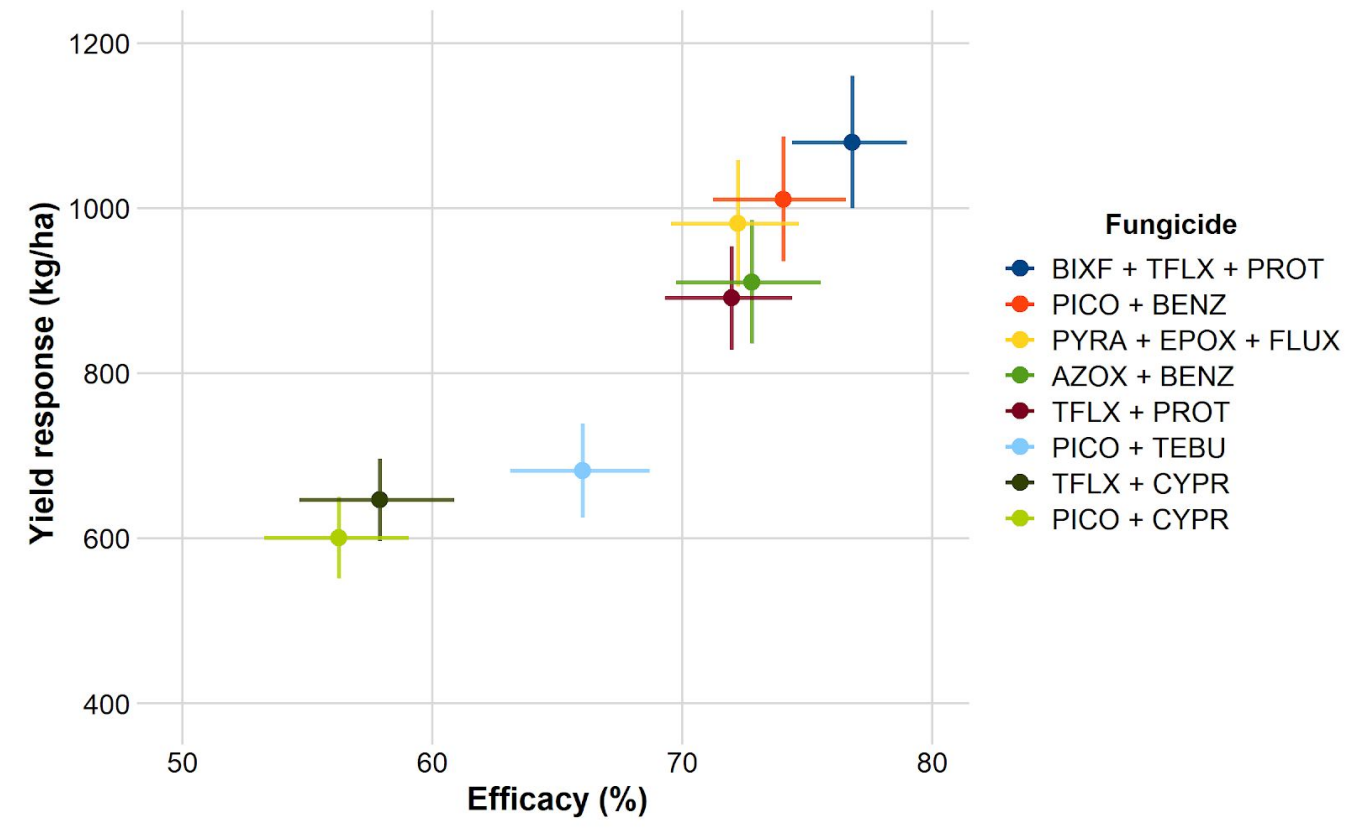

Fig. 3: Relationship between percent reduction of soybean rust (SBR) and yield response relative to untreated check, for eight fungicides evaluated across 177 independent field trials in Brazil from 2014/15 to 2019/20. Bars show the upper and lower limits of $95 \%$ confidence intervals around point estimates for both responses. See Table 1 for complete information of the evaluated fungicides.

\section{Effect of year on control efficacy and yield response}

The increase in log response ratio for disease severity $\left(\bar{L}_{S E V}\right)$ and consequently reduction in $\bar{C}$ per unit time (characterizing a decline in efficacy) varied among fungicides and the slope was statistically different from zero $(P<0.0001)$ for the only two QoI + SDHI premixes (Table 4): AZOX + BENZ showed the greatest relative reduction in percent control (35.3 percent points) from the first season (2014/15; 83.6\%) compared to the last season (2019/20; 48.3\%); for PICO + BENZ, a reduction of 15.5 percent points in efficacy was observed between 2016/17 (78.5\%) and 2019/20 (63\%) seasons. The other six fungicides showed a relatively stable efficacy over the years, including the two new triple premixes BIXF + TFLX + PROT (75.9 - 75.6\%) and PYRA + EPOX + FLUX (73.2 - 68.1\%) evaluated from $2016 / 17$ to $2019 / 20$ (Fig. 4). 
Table 4. Regression parameters (intercept and slope) for the temporal change in log response ratio for SBR severity $\left(\bar{L}_{\text {Sev }}\right)$ and absolute yield $(\bar{D})$ for each fungicide treatment relative to the untreated check from a meta-analytical model with year as a continuous moderator variable $(\mathrm{P}<0.05)$.

\begin{tabular}{|c|c|c|c|c|c|c|c|c|c|c|}
\hline \multirow[b]{2}{*}{ Fungicide $^{\mathrm{a}}$} & \multirow[b]{2}{*}{$\begin{array}{c}\text { First } \\
\text { Season }^{\mathrm{b}}\end{array}$} & \multirow[b]{2}{*}{ Parameter } & \multicolumn{4}{|c|}{ SBR Severity (log scale) } & \multicolumn{4}{|c|}{ Yield response $\left(\mathrm{kg} \mathrm{ha}^{-1}\right)$} \\
\hline & & & $\bar{L}_{\mathrm{Sev}}$ & $\mathrm{CI}_{\mathrm{L}}^{\mathrm{c}}$ & $\mathrm{CI}_{\mathrm{U}}{ }^{\mathrm{c}}$ & P-value & $\bar{D}$ & $\mathrm{CI}_{\mathrm{L}}{ }^{\mathrm{c}}$ & $\mathrm{CI}_{\mathrm{U}}^{\mathrm{c}}$ & P-value \\
\hline \multirow[t]{2}{*}{ AZOX + BENZ } & $2014 / 15$ & Intercept & -1.808 & -1.981 & -1.634 & $<0.0001$ & 1161.6 & 1039.3 & 1283.9 & $<0.0001$ \\
\hline & - & Slope & 0.229 & 0.167 & 0.292 & $<0.0001$ & -109.8 & -153.7 & -66.0 & $<0.0001$ \\
\hline \multirow[t]{2}{*}{ PICO + BENZ } & $2016 / 17$ & Intercept & -1.901 & -2.166 & -1.635 & $<0.0001$ & 1336.6 & 1175.4 & 1497.8 & $<0.0001$ \\
\hline & - & Slope & 0.181 & 0.101 & 0.260 & $<0.0001$ & -119.9 & -171.6 & -68.1 & $<0.0001$ \\
\hline \multirow{2}{*}{$\begin{array}{l}\text { BIXF + TFLX + } \\
\text { PROT }\end{array}$} & $2016 / 17$ & Intercept & -1.432 & -1.694 & -1.170 & $<0.0001$ & 1025.1 & 840.0 & 1210.2 & $<0.0001$ \\
\hline & - & Slope & 0.003 & -0.074 & 0.082 & 0.9217 & 8.805 & -49.8 & 67.4 & 0.7687 \\
\hline \multirow{2}{*}{$\begin{array}{l}\text { PYRA + EPOX + } \\
\text { FLUX }\end{array}$} & $2016 / 17$ & Intercept & -1.436 & -1.681 & -1.191 & $<0.0001$ & 1055.0 & 876.6 & 1233.4 & $<0.0001$ \\
\hline & - & Slope & 0.058 & -0.015 & 0.132 & 0.1194 & -37.8 & -94.1 & 18.3 & 0.1864 \\
\hline \multirow[t]{2}{*}{ TFLX + PROT } & $2014 / 15$ & Intercept & -1.361 & -1.523 & -1.199 & $<0.0001$ & 927.5 & 815.3 & 1039.7 & $<0.0001$ \\
\hline & - & Slope & 0.037 & -0.018 & 0.093 & 0.1905 & -15.6 & -55.0 & 23.7 & 0.4361 \\
\hline \multirow[t]{2}{*}{ PICO + TEBU } & 2014/15 & Intercept & -1.106 & -1.254 & -0.958 & $<0.0001$ & 627.3 & 527.8 & 726.7 & $<0.0001$ \\
\hline & - & Slope & 0.004 & -0.051 & 0.060 & 0.8783 & 30.4 & -5.7 & 66.7 & 0.0995 \\
\hline \multirow[t]{2}{*}{ TFLX + CYPR } & $2015 / 16$ & Intercept & -0.917 & -1.072 & -0.761 & $<0.0001$ & 655.3 & 561.5 & 749.1 & $<0.0001$ \\
\hline & & Slope & 0.024 & -0.026 & 0.074 & 0.3541 & -4.8 & -37.2 & 27.6 & 0.7715 \\
\hline \multirow[t]{2}{*}{ PICO + CYPR } & $2014 / 15$ & Intercept & -0.841 & -0.960 & -0.722 & $<0.0001$ & 619.3 & 530.8 & 707.7 & $<0.0001$ \\
\hline & - & Slope & 0.006 & -0.034 & 0.047 & 0.7420 & -7.9 & -39.1 & 23.1 & 0.6152 \\
\hline
\end{tabular}

a See Table 1 for complete information of the evaluated fungicides;

${ }^{\mathrm{b}}$ First season in which the fungicide was tested in the SBR uniform fungicide trial;

${ }^{\mathrm{c}} \operatorname{Upper}\left(\mathbf{C I}_{\mathrm{U}}\right)$ and lower $\left(\mathbf{C I}_{\mathrm{L}}\right)$ limits of the $95 \%$ confidence interval around $\bar{L}_{\text {Sev }}$ and $\bar{D}$. 


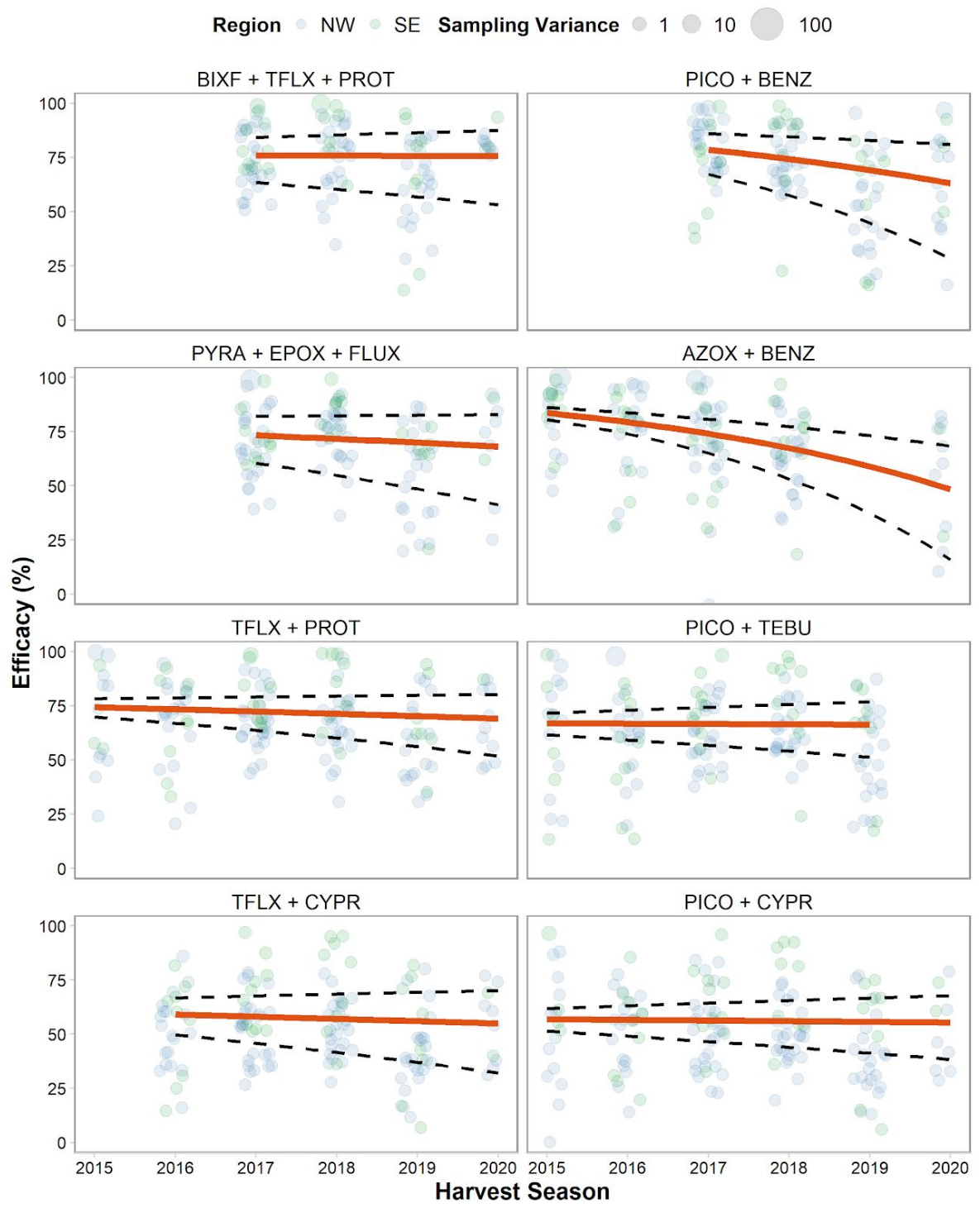

Fig. 4. Yearly variation of efficacy (percent control) for eight selected fungicide treatments applied three times during the season for the control of soybean rust. Solid (mean) and dashed (95\% CIs) lines are the predictions from back-transforming the log response ratio for each year based on the intercepts and slopes (Table 4) of network meta-regression models using year as a continuous covariate. Each dot represent the observed efficacy in an individual trial given by $100 *\left[1-\left(\operatorname{Sev}_{\mathrm{Fung}} / \mathrm{Sev}_{\mathrm{Check}}\right)\right]$, colored by two geographic regions defined in our study: Northwestern (NW) states (MT, MS, GO, BA, DF, TO, MG) and Southeastern (SE) states (PR, RS, SP). See Table 1 for detailed information on the fungicide treatments.

Similarly, slopes for $\bar{D}$ over time were statistically different from zero $(\mathrm{P}<$ 0.0001) for only AZOX + BENZ and PICO + BENZ, (Table 4). The greatest reduction in yield response (550 kg/ha) was observed for AZOX + BENZ $(1,161 \mathrm{~kg} / \mathrm{ha}$ in $2014 / 15$ compared with $611 \mathrm{~kg} / \mathrm{ha}$ in 2019/20). For PICO + BENZ, a reduction of $359.8 \mathrm{~kg} / \mathrm{ha}$ was observed during the four-year period in which the premix was evaluated $(1,096.7 \mathrm{~kg} / \mathrm{ha}$ in 2016/17 compared with $736.9 \mathrm{~kg} / \mathrm{ha}$ in 2019/20) (Fig. $5)$. 


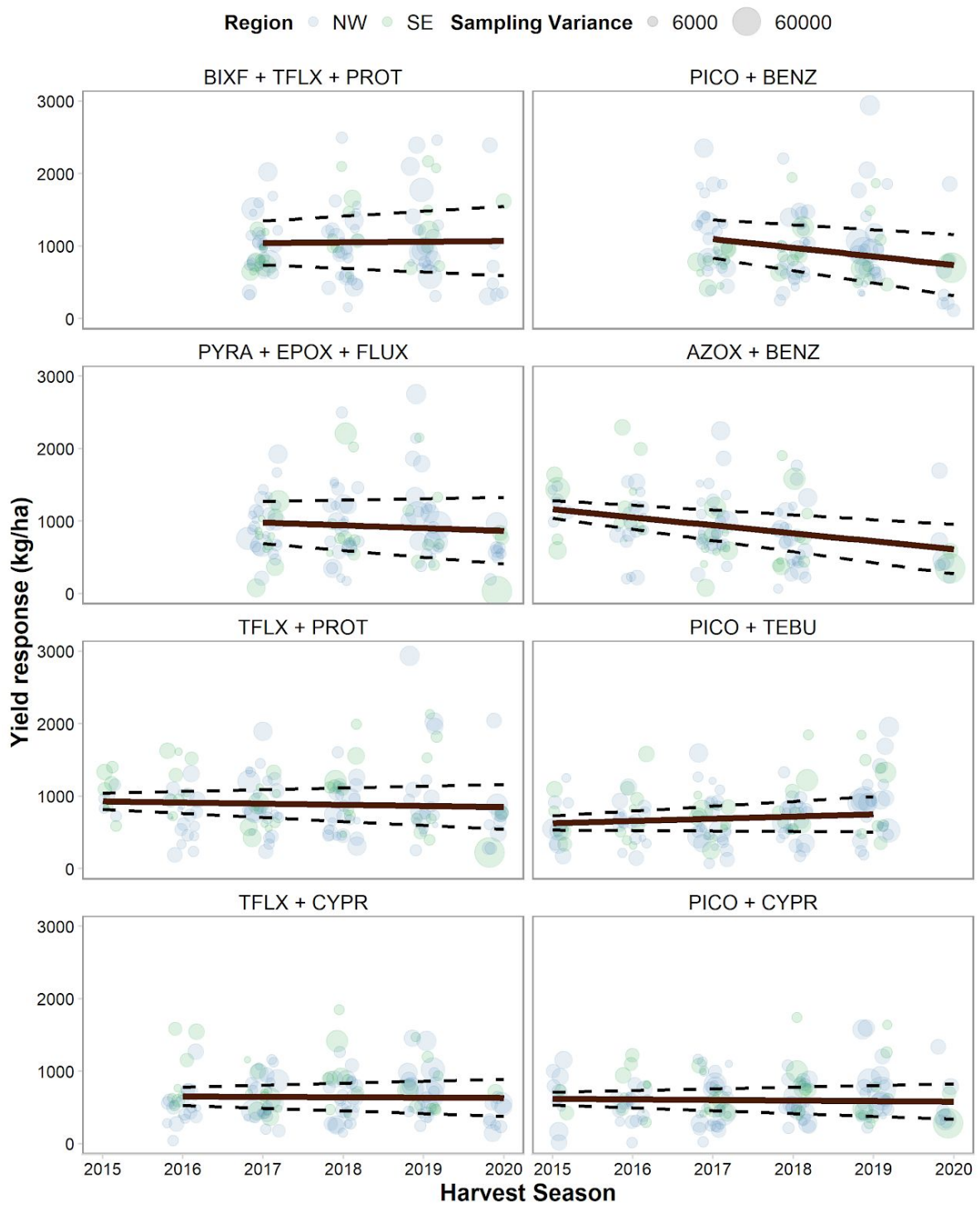

Fig. 5. Yearly variation in the difference in yield in the fungicide-treated plot and the untreated plot (yield response) for eight fungicide treatments applied three times during the season for the control of soybean rust. Solid (mean) and dashed (95\% CIs) lines represent the predictions by a network meta-regression modeling where with year was included as a continuous covariate. Each dot represents the observed yield response at each trial colored by two geographic regions defined in our study: Northwestern (NW) states (MT, MS, GO, BA, DF, TO, MG) and Southeastern (SE) states (PR, RS, SP). See Table 1 for detailed information on the fungicide treatments.

\section{Region effect on control efficacy and yield response}

Based on the Wald test $(\mathrm{P}<0.0001)$, the expanded model including the categorical moderator variable region differed statistically from the simpler model for both disease severity and yield response. The control efficacy in the SE region was numerically higher compared to the NW region for all treatments (Fig. 6). The lowest mean percent control for the two treatments whose performance declined 
over time, in the NW region, was determined for AZOX + BENZ (28\%) and PICO + BENZ (51\%) at the municipalities of Cabeceira do Apa (MS) and Diamantino (MT), respectively (Fig. 2). For the SE region, the lowest efficacies estimated for AZOX + BENZ and PICO + BENZ, were determined in the southernmost state, RS, in Itaara (57\%) and Erebango (16\%) (Fig. 2). A difference of at least 7.4 percent points in $\bar{C}$ between regions was significant $(P<0.05)$ for five fungicides $(\mathrm{BIXF}+\mathrm{TFLX}+$ PROT, PICO + CYPR, PICO + TEBU, TFLX + CYPR and TFLX + PROT) (Table S3; Fig. $6)$.

Similarly, yield response from the use of fungicides was generally higher in the SE than in the NW, except for the premix PICO + BENZ. There was a statistical difference in $\bar{D}$ between regions for four fungicides (PICO + CYPR, PICO + TEBU, TFLX + CYPR and TFLX + PROT), with yield responses ranging from 130 to $203 \mathrm{~kg} / \mathrm{ha}$ (Table S3; Fig. 6).

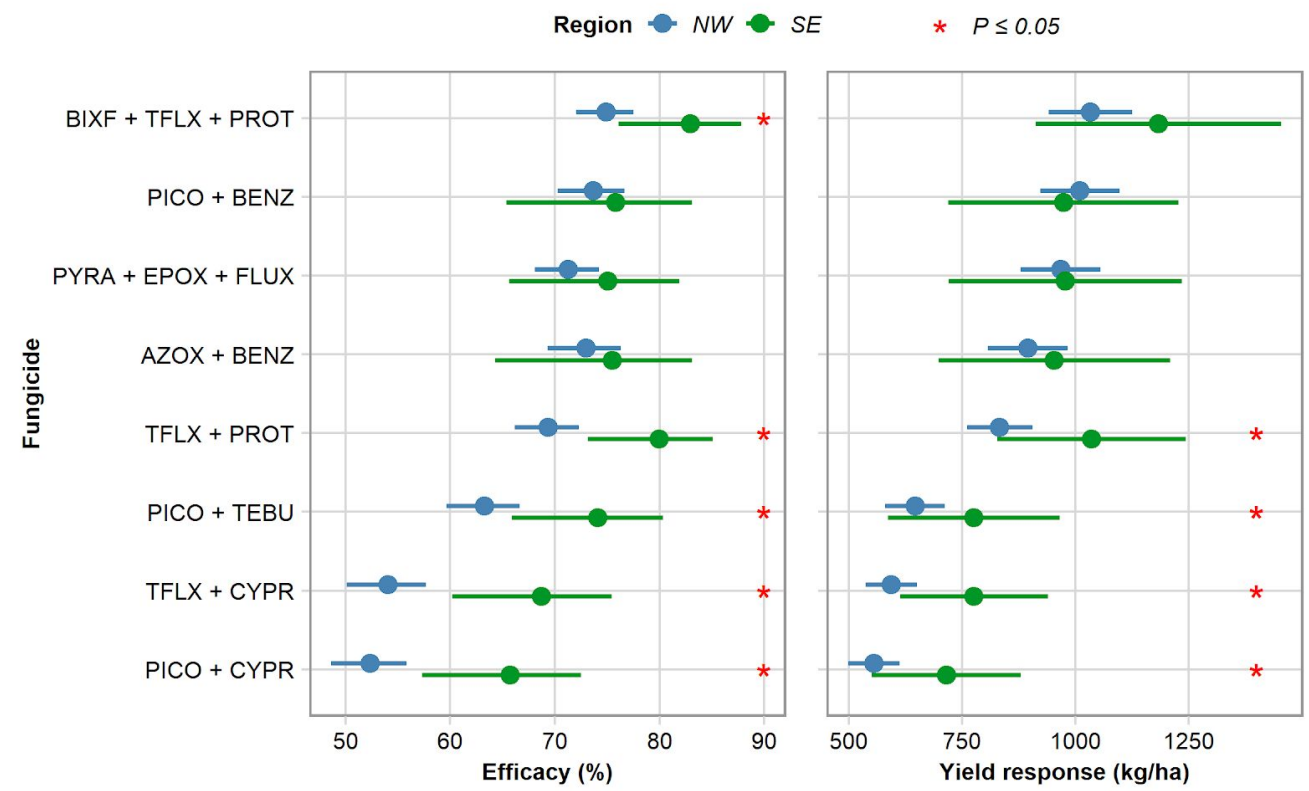

Fig. 6. Means and respective $95 \%$ confidence interval (error bars) for control efficacy (\%) and soybean yield response $\left(\mathrm{kg} \mathrm{ha}^{-1}\right)$ provided by fungicide treatments evaluated from 2015 to 2020 years and grouped into two geographic regions defined in our study: Northwestern (NW) states (MT, MS, GO, BA, DF, TO, MG) and Southeastern (SE) states (PR, RS, SP). The means were calculated from back-transforming estimates by a network meta-analytic model where region was included as covariate. See Table 1 for detailed information on the fungicide treatments.

\section{Effect of baseline disease on yield response}

The expanded model including the categorical interaction term (baseline severity) differed statistically from the simpler model based on the Wald test $(P<0.05)$, 
meaning that severity in the untreated check treatment explained at least portion of the variability in yield response. In general, $\bar{D}$ was greater in the high-disease than in the low disease scenarios, with differences ranging from from $107 \mathrm{~kg} / \mathrm{ha}$ $(\mathrm{PICO}+\mathrm{TEBU})$ to $250 \mathrm{~kg} / \mathrm{ha}(\mathrm{PICO}+\mathrm{BENZ})$ among treatments (Table 5).

Table 5. Overall means of soybean yield response $(\bar{D})$ for each fungicide treatment, relative to the untreated check, conditioned (moderator analysis) to two classes of soybean rust severity representing a low $(<70 \%$ in the untreated check) or high disease pressure $(>70 \%$ in the untreated check).

\begin{tabular}{|c|c|c|c|c|c|c|}
\hline \multirow[b]{2}{*}{ Fungicide $^{a}$} & \multirow[b]{2}{*}{ Condition } & \multicolumn{5}{|c|}{ Yield response $\left(\mathrm{kg} \mathrm{ha}^{-1}\right)$} \\
\hline & & $k^{\mathrm{b}}$ & $\bar{D}$ & $\mathrm{CI}_{\mathrm{L}}^{\mathrm{c}}$ & $\mathrm{CI}_{\mathrm{U}}^{\mathrm{c}}$ & P-value \\
\hline \multirow[t]{2}{*}{ AZOX + BENZ } & High & 82 & 1005.3 & 908.0 & 1102.5 & 0.0035 \\
\hline & Low & 63 & 784.5 & 539.0 & 1029.9 & \\
\hline \multirow[t]{2}{*}{ BIXF+TFLX+PROT } & High & 63 & 1154.1 & 1048.4 & 1259.9 & 0.0352 \\
\hline & Low & 53 & 982.7 & 717.4 & 1248.0 & \\
\hline \multirow[t]{2}{*}{ PICO + BENZ } & High & 63 & 1119.6 & 1021.3 & 1217.8 & 0.0009 \\
\hline & Low & 55 & 869.3 & 623.0 & 1115.6 & \\
\hline \multirow[t]{2}{*}{ PICO + CYPR } & High & 100 & 651.0 & 586.5 & 715.6 & 0.0196 \\
\hline & Low & 75 & 533.7 & 370.6 & 696.7 & \\
\hline \multirow[t]{2}{*}{ PICO + TEBU } & High & 93 & 728.4 & 654.4 & 802.4 & 0.0654 \\
\hline & Low & 61 & 621.3 & 433.3 & 809.3 & \\
\hline \multirow[t]{2}{*}{ PYRA+EPOX+FLUX } & High & 61 & 1088.0 & 988.5 & 1187.5 & 0.0019 \\
\hline & Low & 55 & 850.7 & 601.6 & 1099.8 & \\
\hline \multirow[t]{2}{*}{ TFLX + CYPR } & High & 80 & 707.2 & 642.3 & 772.1 & 0.0061 \\
\hline & Low & 66 & 569.6 & 406.3 & 732.9 & \\
\hline \multirow[t]{2}{*}{ TFLX + PROT } & High & 96 & 956.3 & 874.5 & 1038.2 & 0.0174 \\
\hline & Low & 73 & 804.7 & 597.9 & 1011.5 & \\
\hline
\end{tabular}

a See Table 1 for complete information of the evaluated fungicides;

${ }^{\mathrm{b}}$ Number of trials that each fungicide was evaluated;

${ }^{c}$ Upper $\left(\mathbf{C I}_{\mathrm{U}}\right)$ and lower $\left(\mathbf{C I}_{\mathrm{L}}\right)$ limits of the $95 \%$ confidence interval around $\bar{D}$. 


\section{Economic analysis}

Overall, all fungicides were profitable, but especially the triple premix BIXF + TFLX + PROT; medians profit of US\$186.05/ha and US\$230.68/ha for the NW and the SE regions, respectively (Fig. 7). The lowest profit levels were obtained by AZOX + BENZ; median value of US\$73.39/ha and US\$55.48/ha for NW and SE regions, respectively. Two dual premixes, AZOX + BENZ and PICO + BENZ, which were the fungicides whose performance declined over time, were the only yielding negative 0.025 quantiles in their profit distributions (Fig. 7). Overall, the more profitable scenarios were observed for the SE region, approximately $30 \%$ superior than in the NW region.

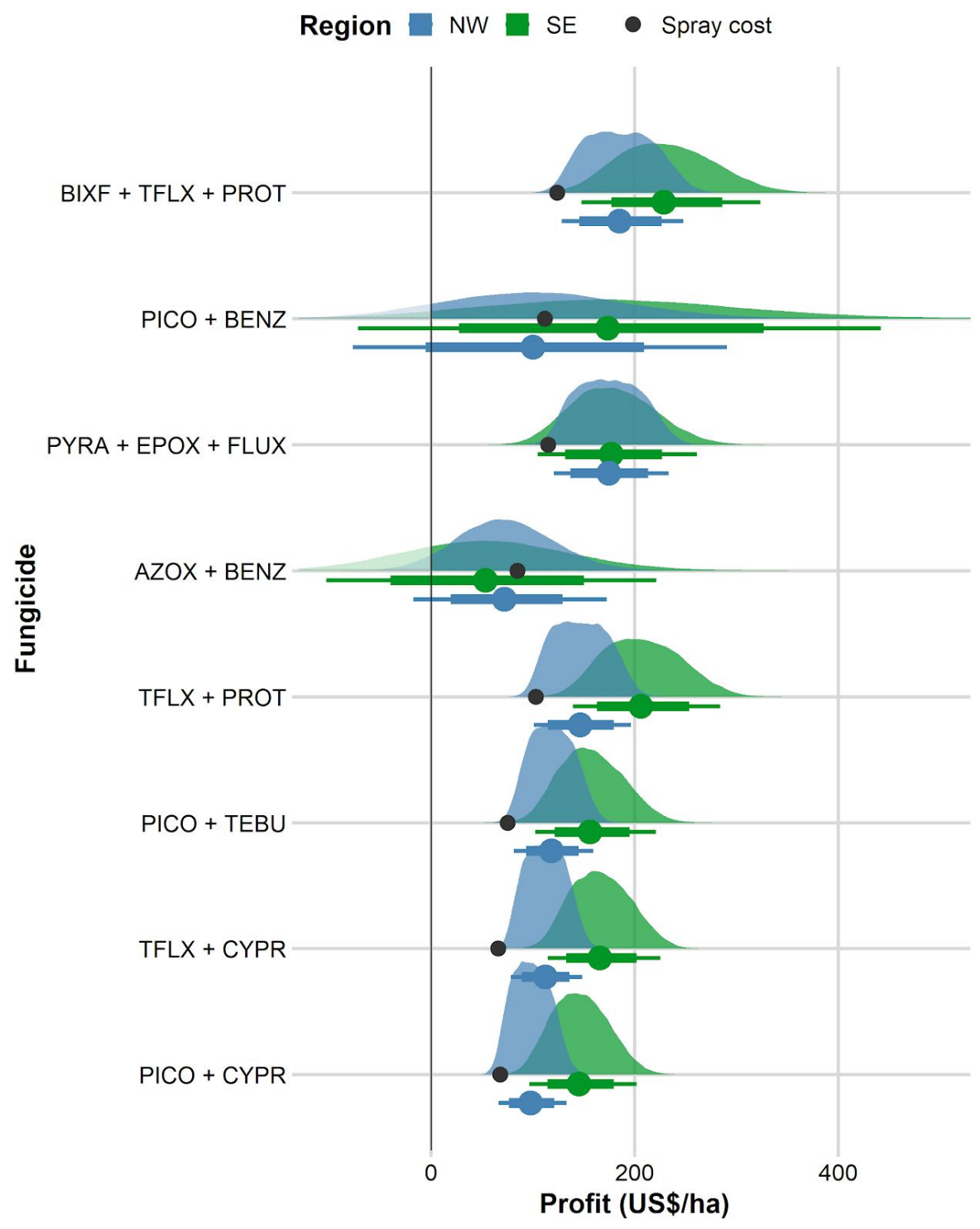

Fig. 7. Half-eye plots (a density and interval) of profits (40,000 simulation runs) based on the meta-analytic estimate of yield response $\left(\mathrm{kg} \mathrm{ha}^{-1}\right)$ for eight fungicide treatments conditioned of two geographic regions: Northwestern (NW) states (MT, MS, GO, BA, DF, 
TO, MG) and Southeastern (SE) states (PR, RS, SP) of Brazil, evaluated during six years (2015 to 2020). The profits of each fungicide:region combination were calculated by subtracting costs with sprays (see black dot in the figure for specific cost for the fungicide) from the income (US\$/ha) given by yield response times soybean price. Bars show the upper and lower limits of $95 \%$ confidence intervals around point estimates. See Table 1 for detailed information on the fungicide treatments and costs.

\section{Discussion}

The present study updates critical information on the management of soybean rust with fungicides in Brazil during the past six growing seasons (2014/15 $2019 / 20$ ) across the main soybean-producing states. On average, we found the best performing and most stable fungicide premix as one of the three-group mixture (BIXF + TFLX + PROT); the poor performing ones were two QoI + DMI dual mixtures (TFLX + CYPR and PICO + CYPR). A statistically significant decline in performance was detected for two dual premixes of QoI + SDHI fungicides $(\mathrm{AZOX}+\mathrm{BENZ}$ and PICO + BENZ). Finally, we found generally greater levels of SBR control in the Southeastern region and in trials with conditions favorable for severe epidemics (severity in the untreated check greater than 70\%).

In comparison to our previous meta-analysis (Dalla Lana et al. 2018) that used a 10-year dataset (up to 2014), we included two triple premixes (BIXF + TFLX + PROT and PYRA + EPOX + FLUX) and four dual premixes (AZOX + BENZ, PICO + BENZ, PICO + TEBU and TFLX + CYPR), which were not evaluated previously. In that study, the dual premix PICO + CYPR (80.2\%) performed the best among all fungicides. In our updated analysis, its efficacy reduced in 24 percent points (56\% on average) than in that previous period. This difference confirms the trend of significant decline in control efficacy determined previously for this premix after seven years of use (2006/07 - 2013/14). Further decline was not detected for PICO + CYPR in our analysis, meaning that the reduced levels have been maintained during the six growing seasons and the large spatial variation in efficacy prevented us from detecting significant trends in fungicide performance over time.

Our results are also confirmatory of the stability in the performance of TFLX + PROT over the years, with no decline being detected, on average, during the previous period (Dalla Lana et al. 2018). The higher efficacy of the triple mixture (TFLX + PROT + BIXF) could not only be attributed to the addition of BIXF, since the amount of TFLX and PROT a.i./ha $(75+87.5)$ in the triple mixture is superior than in the dual mixture (TFLX $60+$ PROT 70). A recent two-year 
study, not included in our analysis, and conducted in the north of RS state (Sacon et al. 2020) reported a 71\% efficacy for TFLX + PROT, which was close to our overall estimates (72\%), but both were numerically lower than the previous meta-analysis (83.6\%) (Dalla Lana et al. 2018). Additionally, the authors found similar SBR control efficacy for PYRA + EPOX + FLUX (>70\%) (Sacon et al. 2020) compared to the estimates reported here (72\%).

In general, relatively lower levels of percent control and yield response were observed for the Northwestern region, which could be explained by the greatest disease pressure on those states as reported previously (Scherm et al. 2009) and where the within-season average number of sprays of fungicides is usually higher than in the southern states, and so where issues with fungicide resistance are more expected (Godoy et al. 2016a). Accordingly, more profitable scenarios ( 30\%) were calculated for the Southeastern region. The increased levels of yield return during more severity epidemics conditions agrees with previous studies on the effect of fungicides for other diseases of soybean and other crops, suggesting a more likely benefit than when disease pressure is low to moderate (Delaney et al. 2018; Edwards Molina et al. 2018; Barro et al. 2019).

The reduction in control efficacy and yield response reported here for $\mathrm{AZOX}+\mathrm{BENZ}$ and PICO $+\mathrm{BENZ}$ is possibly linked to reports of P. pachyrhizi resistant populations to QoIs (Klosowski et al. 2016) and more recently, the SDHI (Simões et al. 2018). Regarding QoIs, Dalla Lana et al. (2018) identified a decline for the performance of QoI applied either as a single a.i. and as a premix amended with cyproconazole. The reduction of sensitivity to QoI has been clearly associated with the occurrence of the F129L substitution, caused by target site mutations at the CYTB, which was first reported in P. pachyrhizi isolates collected in 2012/13, increasing in frequency in 2013/14 (Klosowski et al. 2016). Although cross-resistance in the same group occurs, the mutations affect the active ingredients in different ways. For QoIs, F129L mutation presents a quantitative effect in P. pachyrhizi, and affects the performance of azoxystrobin and pyraclostrobin more than other active ingredients, including picoxystrobin, trifloxystrobin, and metominostrobin (Godoy and Meyer 2020).

Reduction in the sensitivity of P. pachyrhizi isolates to SDHI was first reported in the 2015/16 crop season, linked to a mutation in the SdhC gene causing the amino acid substitution C-I86F (Simões et al. 2018). According to the authors, the C-186F mutation was not detected before SDHI market introduction, 
and the mutation frequency was lower in samples collected from untreated plots compared to SDHI-treated plots in several field trials. Additionally, C-186F frequency increased in the 2016/17 season and the mutation was found in $P$. pachyrhizi populations from various and distinct regions in Brazil, accelerating the occurrence of resistance (Simões et al. 2018).

The use of cultivars with resistance genes (Rpp) to SBR has been more widely adopted to improve SBR management and to reduce the selection pressure of fungicides (Childs et al. 2018). However, the sole use of resistant cultivars as management choice has the same limitations of the fungicide use, which is the selection of pathogen populations capable of overcoming the Rpp genes (Godoy et al. 2016a). Therefore, recent studies have investigated the interaction effect of chemical and genetic control (Bahry et al. 2020; Sacon et al. 2020). A two-year study $(2016 / 17$ to 2017/18) conducted in Paraná state found a significant reduction in SBR severity combining fungicide treatment (AZOX + BENZ) with a resistant cultivar (TMG 7062; 72\%); followed by the highly tolerant (LG 60163; $\sim 64 \%$ ) and the susceptible cultivar (NA 5909; 52.1\%) (Bahry et al. 2020). Sacon et al. (2020) also reported higher SBR control applying AZOX + BENZ in resistant cultivars (>80\%) compared to a susceptible one ( 56\%) in field experiments conducted in Northern Rio Grande do Sul state during 2016/17 and 2017/18 growing seasons.

Another ongoing strategy to improve SBR control and to reduce the risk of resistance development is to alternate modes of action and the use of premixes of single-site amended with multi-site fungicides (Godoy et al. 2016a). In fact, a recent two-year study (2016/17 to 2017/18) reported significant gain values in SBR control efficacy for TFLX + PROT (14\%) and AZOX + BENZ (28\%) amended with mancozeb (Netto et al. 2020). Preliminary data from the Cooperative fungicide trials have also shown benefits from adding multi-site fungicides (Godoy et al. 2016c, 2017b, 2018b) and more data becoming available in the near future should be amenable for meta-analysis, and so quantitatively estimate the benefits of multi-site fungicides.

In conclusion, the results of our study provide critical information to support decision making during fungicide planning with the goal of maximizing profit during the season but also decisions on deployment of fungicides to mitigate fungicide resistance. The continuing evaluation of fungicides by the CFT is essential and should be encouraged. The results obtained in this study are also 
useful when choosing the fungicides to be tested in future trials. Finally, the suspension of the registration of non effective fungicides can help to manage fungicide resistance, which may be, at least, partially reversible when the selection pressure of fungicide is removed or minimized (Parnell et al. 2005). For instance, the efficacy of tebuconazole applied as single a.i., which showed the greatest rate of reduction (7.7 p.p. year ${ }^{-1}$ ) in the previous study (Dalla Lana et al. 2018), is recovering efficacy during the last crop seasons (Godoy et al. 2020).

\section{Acknowledgements}

The first and senior author acknowledges the financial support provided by the Conselho Nacional de Desenvolvimento Científico e Tecnológico (CNPq/Brazil) for scholarship and research fellowship (PQ-306857/2015-4), respectively. We also acknowledge the financial support provided by the Fundação de Amparo à Pesquisa do Estado de Minas Gerais (Fapemig/Brazil) for a research grant (APQ-03945-16). All other authors are thankful to their institutions and teams for providing support during the conduction of field experiments and the collection of the data.

\section{Data availability statement}

The data and R scripts that support the findings of this study are openly available in the Open Science Framework project at osf.io/zjfyg/. A website was generated to better visualize the scripts where all data and analyses are documented and reproducible (https://git.io/JtPaY).

\section{Author's contribution}

JPB, KSA and EMD conceived the idea, analysed the data and wrote the manuscript. CVG planned and coordinated the experiments; ARD, CAF, CM U, ERAJ, FCJ, FJG, HRF, HDC, ICPVC, IPAJ, JMTR, JNJ, LMRB, LCC, LHCPS, MGC, MMGJ, MS, MCM, MDD, MAM, MCM, MPD, NRT, SHF, TFK, VJC and WSV conducted the field trials and shared the data. All authors provided feedback and approved the final manuscript. 


\section{Conflict of interests}

The authors declare that they have no conflict of interests.

\section{Literature Cited}

AGROLINK. (2020) Cotações. Available at: https://www.agrolink.com.br/cotacoes/ [Accessed January $30,2020]$.

Bahry, C. A., Ceresoli, L., Carleso, Â. A., Prá, F. S. D., Petkowicz, L. A., Geraldo, G. et al. (2020) Analysis of combined strategies for the management of Asian soybean rust. African Journal of Plant Science, 14, 297-307.

Barro, J. P., Meyer, M. C., Godoy, C. V., Dias, A. R., Utiamada, C. M., Jaccoud Filho, D. de S. et al. (2019) Performance and profitability of fungicides for managing soybean white mold: a 10-year summary of cooperative trials. Plant Disease, 103, 2212-2220.

Beruski, G. C., Del Ponte, E. M., Pereira, A. B., Gleason, M. L., Câmara, G. M. S., Araújo Junior, I. P., and Sentelhas, P. C. (2020) Performance and profitability of rain-based thresholds for timing fungicide applications in Soybean rust control. Plant Disease doi:10.1094/PDIS-01-20-0210-RE.

Childs, S. P., Buck, J. W., and Li, Z. (2018) Breeding soybeans with resistance to soybean rust (Phakopsora pachyrhizi). Plant Breeding, 137, 250-261.

Dalla Lana, F., Ziegelmann, P. K., Maia, A. de H. N., Godoy, C. V., and Del Ponte, E. M. (2015) Meta-analysis of the relationship between crop yield and soybean rust severity. Phytopathology, $105,307-315$.

Dalla Lana, F., Paul, P. A., Godoy, C. V., Utiamada, C. M., da Silva, L. H. C. P., Siqueri, F. V., Forcelini, C. A. et al. (2018) Meta-analytic modeling of the decline in performance of fungicides for managing soybean rust after a decade of use in Brazil. Plant Disease, 102, 807-817.

Delaney, M., ArchMiller, A. A., Delaney, D. P., Wilson, A. E., and Sikora, E. J. (2018) Effectiveness of fungicide on soybean rust in the Southeastern United States: a meta-analysis. Sustainability. 10:1784.

Edwards-Molina, J. P., Paul, P. A., Amorim, L., Silva, L. H. C. P., Siqueri, F. V., Borges, E. P. et al. (2018) Meta-analysis of fungicide efficacy on soybean target spot and cost-benefit assessment. Plant Pathology, 68, 94-106.

Godoy, C. V., Koga, L. J., Canteri, M. G.. (2006) Diagrammatic scale for assessment of soybean rust severity. Fitopatologia Brasileira, 31,63-68.

Godoy, C. V., and Meyer, M. C. (2020) Overcoming the threat of Asian soybean rust in Brazil. In: Deising, H. B., Fraaije, B., Mehl, A., Oerke, E. C., Sierotzki, H., and Stammler, G. (Eds), Modern Fungicides and Antifungal Compounds, Vol. IX, pp. 51-56. Deutsche Phytomedizinische Gesellschaft, Braunschweig, ISBN: 978-3-941261-16-7

Godoy, C. V., Utimada, C. M., Meyer, M. C., Campos, H. D., Forcelini, C. A., Pimenta, C. B. et al. (2015) Eficiência de fungicidas para o controle da ferrugem-asiática da soja, Phakopsora pachyrhizi, na safra 2014/15: resultados sumarizados dos ensaios cooperativos. Circular técnica 111. Embrapa Soja, Londrina, Brazil.

Godoy, C. V., Seixas, C. D. S., Soares, R. M., Marcelino-Guimarães, F. C., Meyer, M. C., and Costamilan, L. M. (2016a) Asian soybean rust in Brazil: past, present, and future. Pesquisa Agropecuária Brasileira, 51, 407-421.

Godoy, C. V., Utiamada, C. M., Meyer, M. C., Campos, H. D., Forcelini, C. A., Pimenta, C. B. et al. (2016b) Eficiência de fungicidas para o controle da ferrugem-asiática da soja, Phakopsora pachyrhizi, na safra 2015/16: resultados sumarizados dos ensaios cooperativos. Circular técnica 119. Embrapa Soja, Londrina, Brazil. 
Godoy, C. V., Utiamada, C. M., Meyer, M. C., Campos, H. D., Forcelini, C. A., Pimenta, C. B. et al. (2016c) Eficiência de fungicidas multissítios no controle da ferrugem-asiática da soja, Phakopsora pachyrhizi, na safra 2015/16: resultados sumarizados dos ensaios cooperativos. Circular técnica 121. Embrapa Soja, Londrina, Brazil.

Godoy, C. V., Utiamada, C. M., Meyer, M. C., Campos, H. D., Lopes, I. O. N., Forcelini, C. A. et al. (2017a) Eficiência de fungicidas para o controle da ferrugem-asiática da soja, Phakopsora pachyrhizi, na safra 2016/17: resultados sumarizados dos ensaios cooperativos Circular técnica 129. Embrapa Soja, Londrina, Brazil.

Godoy, C. V., Utiamada, C. M., Meyer, M. C., Campos, H. D., Lopes, I. O. N., Forcelini, C. A. et al. (2017b) Eficiência de fungicidas multissítios e produto biológico no controle da ferrugem asiática da soja, Phakopsora pachyrhizi, na safra 2016/17: resultados sumarizados dos ensaios cooperativos. Circular técnica 131. Embrapa Soja, Londrina, Brazil.

Godoy, C. V., Utiamada, C. M., Meyer, M. C., Campos, H. D., Lopes, I. O. N., Dias, A. R. et al. (2018a) Eficiência de fungicidas para o controle da ferrugem-asiática da soja, Phakopsora pachyrhizi, na safra 2017/2018: Resultados sumarizados dos ensaios cooperativos. Circular técnica 138. Embrapa Soja, Londrina, Brazil.

Godoy, C. V., Utiamada, C. M., Meyer, M. C., Campos, H. D., Lopes, I. O. N., Dias, A. R., Deuner, C. C. et al. (2018b) Eficiência de fungicidas multissítios no controle da ferrugem-asiática da soja, Phakopsora pachyrhizi, na safra 2017/18: resultados sumarizados dos ensaios cooperativos. Circular técnica 144. Embrapa Soja, Londrina, Brazil.

Godoy, C. V., Utiamada, C. M., Meyer, M. C., Campos, H. D., Lopes, I. O. N., Dias, A. R., Pimenta, C. B. et al. (2019) Eficiência de fungicidas para o controle da ferrugem-asiática da soja, Phakopsora pachyrhizi, na safra 2019/19: resultados sumarizados dos ensaios cooperativos. Circular técnica 148. Embrapa Soja, Londrina, Brazil.

Godoy, C. V., Utiamada, C. M., Meyer, M. C., Campos, H. D., Lopes, I. O. N., Dias, A. R. et al. (2020) Eficiência de fungicidas para o controle da ferrugem-asiática da soja, Phakopsora pachyrhizi, na safra 2019/2020: resultados sumarizados dos ensaios cooperativos. Circular técnica 160. Embrapa Soja, Londrina, Brazil.

Goellner, K., Loehrer, M., Langenbach, C., Conrath, U., Koch, E., and Schaffrath, U. (2010) Phakopsora pachyrhizi, the causal agent of Asian soybean rust. Molecular Plant Pathology, 11, 169-177.

Higgins, J. P. T., Jackson, D., Barrett, J. K., Lu, G., Ades, A. E., and White, I. R. (2012) Consistency and inconsistency in network meta-analysis: concepts and models for multi-arm studies. Research Synthesis Methods, 3, 98-110.

Hollomon, D. W. (2015) Fungicide Resistance: Facing the Challenge. 51:7.

Klosowski, A. C., May De Mio, L. L., Miessner, S., Rodrigues, R., and Stammler, G. (2016) Detection of the F129L mutation in the cytochrome b gene in Phakopsora pachyrhizi. Pest Management Science, $72,1211-1215$.

Li, X., Esker, P. D., Pan, Z., Dias, A. P., Xue, L., and Yang, X. B. (2010) The uniqueness of the soybean rust pathosystem: an improved understanding of the risk in different regions of the world. Plant Disease, 94, 796-806.

Machado, F. J., Santana, F. M., Lau, D., and Del Ponte, E. M. (2017) Quantitative review of the effects of triazole and benzimidazole fungicides on Fusarium head blight and wheat yield in Brazil. Plant Disease, 101, 1633-1641.

Madden, L. V., Piepho, H.-P., and Paul, P. A. (2016) Statistical models and methods for network meta-analysis. Phytopathology, 106, 792-806.

Netto, A., Sacon, D., Gallina, A., Fochesatto, M., Spitza Stefanski, F., and Mendes Milanesi, P. (2020) Use of systemic fungicides combined with multisite to control of asian rust and soybean yield. Colloquium Agrariae, 16, 101-108.

Parnell, S., Gilligan, C. A., and van den Bosch, F. (2005) Small-scale fungicide spray heterogeneity and the coexistence of resistant and sensitive pathogen strains. Phytopathology, 95, 632-639.

Paul, P. A., Lipps, P. E., Hershman, D. E., McMullen, M. P., Draper, M. A., and Madden, L. V. (2008) Efficacy of triazole-based fungicides for Fusarium head blight and deoxynivalenol control in wheat: a multivariate meta-analysis. Phytopathology, 98, 999-1011. 
Paul, P. A., McMullen, M. P., Hershman, D. E., and Madden, L. V. (2010) Meta-analysis of the effects of triazole-based fungicides on wheat yield and test weight as influenced by Fusarium head blight intensity. Phytopathology, 100, 160-171.

Piepho, H.-P. (2014) Network-meta analysis made easy: detection of inconsistency using factorial analysis-of-variance models. BMC Medical Research Methodology, 14:61.

R Core Team. (2020) R: A language and environment for statistical computing. R Foundation for Statistical Computing, Vienna, Austria. https://www.R-project.org/.

Sacon, D., Netto, A., Fochesatto, M., Stefanski, F. S., Gallina, A., Milanesi, P. M., et al. (2020) Integration between genetic and chemical control on the progress of Asian soybean rust and yield. Summa Phytopathologica, 46, 198-204.

Scherm, H., Christiano, R. S. C., Esker, P. D., Del Ponte, E. M., and Godoy, C. V. (2009) Quantitative review of fungicide efficacy trials for managing soybean rust in Brazil. Crop Protection, 28, 774-782.

Schmitz, H. K., Medeiros, C.-A., Craig, I. R., and Stammler, G. (2013) Sensitivity of Phakopsora pachyrhizi towards quinone-outside-inhibitors and demethylation-inhibitors, and corresponding resistance mechanisms. Pest Management Science, 70, 378-388.

Simões, K., Hawlik, A., Rehfus, A., Gava, F., and Stammler, G. (2018) First detection of a SDH variant with reduced SDHI sensitivity in Phakopsora pachyrhizi. Journal of Plant Diseases and Protection, 125, 21-26.

Viechtbauer, W. (2010) Conducting meta-analyses in R with the metafor Package. Journal of Statistical Software, 36, 1-48.

Yorinori, J. T., Paiva, W. M., Frederick, R. D., Costamilan, L. M., Bertagnolli, P. F., Hartman, G. E., et al. (2005) Epidemics of soybean rust ( Phakopsora pachyrhizi ) in Brazil and Paraguay from 2001 to 2003. Plant Disease, 89, 675-677. 


\section{Supplemental information}
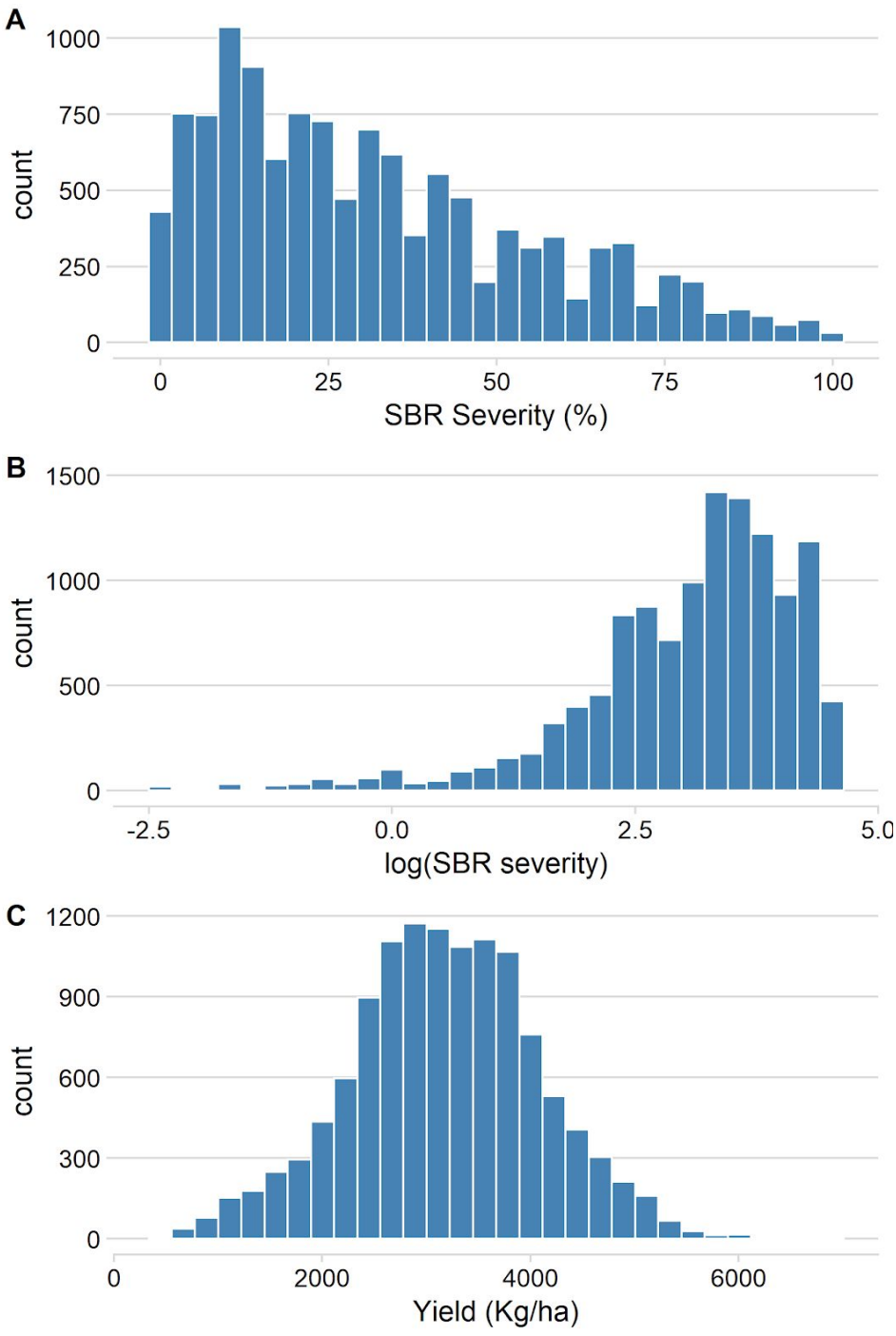

Fig. S1: Histograms for the distribution of SBR severity (A) and soybean yield (C) to check normality; B: log-transformed SBR severity data for normalizing the distribution and use in the meta-analysis. 
Table S1. Designs (set of treatments evaluated in the same trial) identified in 177 independent trials conducted from 2014/15 to 2019/20 across 46 locations in ten Brazilian states (BA, DF, TO, GO, MG, MS, MT, SP, PR and RS).

\begin{tabular}{|c|c|c|}
\hline Designs $^{a}$ & SBR severity & Yield $^{b}$ \\
\hline $\begin{array}{l}\text { PICO + CYPR; PYRA + EPOX + FLUX; AACHECK; AZOX + BENZ; TFLX + PROT; } \\
\text { BIXF + TFLX + PROT; PICO + TEBU; TFLX + CYPR; PICO + BENZ }\end{array}$ & 66 & 65 \\
\hline $\begin{array}{l}\text { PICO + CYPR; AACHECK; AZOX + BENZ; TFLX + PROT; BIXF + TFLX + PROT; } \\
\text { PICO + TEBU; TFLX + CYPR; PICO + BENZ }\end{array}$ & 1 & 1 \\
\hline $\begin{array}{l}\text { PICO + CYPR; PYRA + EPOX + FLUX; AACHECK; AZOX + BENZ; TFLX + PROT; } \\
\text { BIXF + TFLX + PROT; TFLX + CYPR; PICO + BENZ }\end{array}$ & 21 & 21 \\
\hline $\begin{array}{l}\text { PICO + CYPR; PYRA + EPOX + FLUX; AACHECK; TFLX + PROT; BIXF + TFLX + } \\
\text { PROT; PICO + TEBU; TFLX + CYPR; PICO + BENZ }\end{array}$ & 24 & 23 \\
\hline $\begin{array}{l}\text { PICO + CYPR; PYRA + EPOX + FLUX; AACHECK; AZOX + BENZ; TFLX + PROT; } \\
\text { PICO + TEBU; TFLX + CYPR; PICO + BENZ }\end{array}$ & 2 & 1 \\
\hline $\begin{array}{l}\text { PICO + CYPR; PYRA + EPOX + FLUX; AACHECK; BIXF + TFLX + PROT; PICO + } \\
\text { TEBU; TFLX + CYPR; PICO + BENZ }\end{array}$ & 5 & 5 \\
\hline $\begin{array}{l}\text { PICO + CYPR; AACHECK; BIXF + TFLX + PROT; PICO + TEBU; TFLX + CYPR; } \\
\text { PICO + BENZ }\end{array}$ & 1 & 1 \\
\hline $\begin{array}{l}\text { PICO + CYPR; AACHECK; AZOX + BENZ; TFLX + PROT; PICO + TEBU; TFLX + } \\
\text { CYPR }\end{array}$ & 28 & 28 \\
\hline PICO + CYPR; AACHECK; AZOX + BENZ; TFLX + PROT; PICO + TEBU & 28 & 29 \\
\hline PICO + CYPR; AACHECK; AZOX + BENZ; PICO + TEBU & 1 & - \\
\hline $\begin{array}{l}\text { PICO + CYPR; PYRA + EPOX + FLUX;AACHECK; TFLX + PROT; PICO + TEBU; } \\
\text { TFLX + CYPR; PICO + BENZ }\end{array}$ & - & 1 \\
\hline
\end{tabular}

${ }^{a}$ See Table 1 for complete information about the treatments;

${ }^{\mathrm{b}}$ Number of trials that each design of treatments was identified for both SBR severity and yield. 
Table S2. Observed control efficacy (\%) for each fungicide treatment, relative to the untreated check for each of the 46 locations across ten Brazilian states (BA, DF, GO, MG, MS, MT, PR, RS, SP and TO). Percent efficacy was calculated by $100 *\left[1-\left(\operatorname{Sev}_{\text {Fung }} / \operatorname{Sev}_{\text {Check }}\right)\right]$.

\begin{tabular}{|c|c|c|c|c|c|c|c|c|c|c|}
\hline Location & State & $n$ & $\begin{array}{l}\text { AZOX+ } \\
\text { BENZ }\end{array}$ & $\begin{array}{l}\text { BIXF+TFLX } \\
\text { +PROT }\end{array}$ & $\begin{array}{l}\text { PICO+ } \\
\text { BENZ }\end{array}$ & $\begin{array}{l}\text { PICO+ } \\
\text { CYPR }\end{array}$ & $\begin{array}{l}\text { PYRA+EPOX } \\
\text { +FLUX }\end{array}$ & $\begin{array}{l}\text { TFLX+ } \\
\text { CYPR }\end{array}$ & $\begin{array}{l}\text { TFLX+ } \\
\text { PROT }\end{array}$ & $\begin{array}{l}\text { PICO } \\
+ \text { TEB } \\
\mathrm{U}\end{array}$ \\
\hline $\begin{array}{l}\text { Luís Eduardo } \\
\text { Magalhães }\end{array}$ & BA & 5 & 73.0 & 73.9 & 92.2 & 54.0 & 80.7 & 64.4 & 64.8 & 56.1 \\
\hline Planaltina & $\mathrm{DF}$ & 4 & 61.1 & 69.5 & 63.7 & 47.0 & 64.6 & 48.8 & 59.5 & 57.2 \\
\hline Anápolis & GO & 2 & 29.9 & - & - & 42.5 & - & 45.0 & 61.6 & 56.8 \\
\hline Goiânia & GO & 1 & 59.5 & 61.6 & 68.2 & 32.9 & 54.3 & 33.1 & 60.7 & 45.7 \\
\hline Jataí & GO & 3 & 76.9 & 87.7 & 96.8 & 40.5 & 96.1 & 57.2 & 67.0 & 72.0 \\
\hline Rio Verde & $\mathrm{GO}$ & 12 & 77.4 & 74.8 & 72.2 & 37.5 & 77.0 & 43.0 & 68.6 & 59.5 \\
\hline $\begin{array}{l}\text { Santo Antônio } \\
\text { de Goiás }\end{array}$ & $\mathrm{GO}$ & 1 & 94.4 & - & - & 78.5 & - & - & 89.1 & 81.9 \\
\hline $\begin{array}{l}\text { São Miguel do } \\
\text { Passa Quatro }\end{array}$ & $\mathrm{GO}$ & 2 & 81.9 & 77.3 & 74.8 & 68.9 & 73.7 & 67.3 & 77.1 & 69.8 \\
\hline Senador Canedo & GO & 3 & 83.0 & - & - & 72.5 & - & 60.6 & 75.2 & 75.4 \\
\hline Silvânia & GO & 2 & 81.9 & 81.1 & 81.7 & 71.0 & 77.1 & 70.8 & 82.9 & 75.5 \\
\hline Uberlâmdia & MG & 5 & 81.8 & 70.4 & 64.9 & 55.9 & 63.8 & 49.0 & 77.3 & 58.3 \\
\hline Amambaí & MS & 2 & 66.3 & 71.8 & 65.1 & 44.9 & 71.9 & 50.0 & 61.0 & 50.3 \\
\hline Bonito & MS & 1 & 64.9 & 75.8 & 67.9 & 49.5 & 75.8 & 54.6 & 62.8 & 55.7 \\
\hline $\begin{array}{l}\text { Cabeceira do } \\
\text { Apa }\end{array}$ & MS & 1 & 28.7 & 63.9 & 76.9 & 54.7 & 64.9 & 52.8 & 65.1 & 54.9 \\
\hline Campo Grande & MS & 3 & 82.1 & 53.2 & 60.9 & 43.1 & 59.0 & 42.6 & 70.5 & 47.5 \\
\hline Chapadão do Sul & MS & 7 & 70.7 & 85.4 & 68.0 & 62.8 & 67.0 & 58.8 & 81.8 & 78.6 \\
\hline Maracaju & MS & 5 & 78.5 & 78.4 & 77.0 & 56.8 & 76.6 & 57.9 & 69.2 & 61.6 \\
\hline Naviraí & $\mathrm{MS}$ & 2 & 83.9 & 91.9 & 90.1 & 58.5 & 90.0 & 61.7 & 71.8 & 64.1 \\
\hline $\begin{array}{l}\text { São Gabriel do } \\
\text { Oeste }\end{array}$ & MS & 5 & 76.1 & 75.6 & 77.9 & 52.0 & 76.9 & 51.8 & 63.8 & 54.6 \\
\hline $\begin{array}{l}\text { Campo Novo do } \\
\text { Parecis }\end{array}$ & MT & 5 & 66.8 & 66.6 & 57.0 & 38.9 & 52.5 & 38.7 & 60.0 & 52.8 \\
\hline Campo Verde & MT & 12 & 69.8 & 54.9 & 65.4 & 47.1 & 56.9 & 50.3 & 57.3 & 59.3 \\
\hline Deciolândia & MT & 9 & 58.0 & 69.5 & 59.3 & 38.0 & 55.2 & 37.2 & 67.1 & 56.2 \\
\hline Diamantino & MT & 3 & 84.8 & 53.1 & 51.7 & 30.0 & 36.1 & 35.1 & 47.6 & 43.6 \\
\hline
\end{tabular}




\begin{tabular}{|c|c|c|c|c|c|c|c|c|c|c|}
\hline $\begin{array}{l}\text { Lucas do Rio } \\
\text { Verde }\end{array}$ & MT & 5 & 57.2 & 78.1 & 64.7 & 57.6 & 67.9 & 62.0 & 73.0 & 72.6 \\
\hline Nova Mutum & MT & 3 & 67.6 & 79.5 & 79.6 & 52.4 & 76.2 & 57.4 & 82.7 & 76.9 \\
\hline Nova Xavantina & $\mathrm{MT}$ & 1 & 98.7 & 84.6 & 97.7 & 79.4 & 98.8 & 75.6 & 75.6 & 82.5 \\
\hline Pedra Preta & MT & 6 & 71.0 & 68.3 & 65.1 & 48.8 & 65.1 & 48.1 & 56.1 & 50.2 \\
\hline $\begin{array}{l}\text { Primavera do } \\
\text { Leste }\end{array}$ & MT & 12 & 58.9 & 72.7 & 60.8 & 44.7 & 57.5 & 45.2 & 61.2 & 56.3 \\
\hline Querência & MT & 1 & 68.1 & 79.3 & 65.8 & 36.3 & 65.8 & 31.1 & 80.3 & - \\
\hline Sapezal & MT & 2 & 62.8 & 63.5 & 55.7 & 55.0 & 60.2 & 51.4 & 60.4 & 55.1 \\
\hline Sorriso & MT & 2 & 59.6 & 67.7 & 81.7 & 54.1 & 64.7 & 48.7 & 62.6 & 59.6 \\
\hline Cafelândia & PR & 4 & 57.8 & 65.0 & 68.5 & 54.9 & 71.0 & 48.9 & 50.5 & 57.7 \\
\hline Cascavel & PR & 1 & 92.0 & - & - & 31.0 & - & - & 55.2 & 13.3 \\
\hline Entre Rios & PR & 3 & 91.1 & 90.4 & 90.4 & 71.2 & 86.3 & 78.6 & 88.0 & 93.7 \\
\hline Faxinal & PR & 4 & 61.1 & 95.0 & 66.0 & 65.4 & 69.1 & 69.8 & 89.8 & 78.1 \\
\hline Guarapuava & PR & 1 & 90.9 & - & - & 59.3 & - & 60.3 & 86.6 & 80.1 \\
\hline Londrina & PR & 9 & 67.8 & 85.0 & 63.3 & 59.7 & 75.7 & 63.2 & 69.3 & 59.5 \\
\hline Mauá Da Serra & PR & 3 & 67.0 & 94.4 & 90.6 & 52.0 & 88.1 & 50.5 & 73.8 & 59.1 \\
\hline Palmeira & PR & 5 & 79.8 & 83.6 & 79.7 & 74.7 & 77.5 & 76.2 & 87.5 & 79.9 \\
\hline Ponta Grossa & PR & 5 & 84.2 & 89.3 & 88.9 & 86.3 & 84.2 & 83.0 & 84.3 & 88.9 \\
\hline Erebango & RS & 1 & - & 21.1 & 16.0 & 15.0 & - & 16.9 & - & 21.7 \\
\hline Itaara & RS & 4 & 58.0 & 53.9 & 43.7 & 47.6 & 52.9 & 46.1 & 71.4 & 59.5 \\
\hline Passo Fundo & $\mathrm{RS}$ & 4 & 57.0 & 67.3 & 58.5 & 41.7 & 65.8 & 46.1 & 61.3 & 54.3 \\
\hline Santa Maria & RS & 1 & 92.2 & - & - & 70.6 & - & - & 87.6 & 80.4 \\
\hline Paulínia & SP & 4 & 80.1 & 88.9 & 86.3 & 60.6 & 81.0 & 70.4 & 78.5 & 63.5 \\
\hline Alvorada & $\mathrm{TO}$ & 1 & 65.6 & 65.6 & 63.6 & 65.6 & 71.7 & 47.4 & 63.6 & - \\
\hline
\end{tabular}


Table S3. Overall means of SBR control efficacy $(\bar{C})$ and soybean yield response $(\bar{D})$ for each fungicide treatment, relative to the untreated check, conditioned (moderator analysis) to two geographic regions defined in our study: Northwestern (NW) states (MT, MS, GO, BA, DF, TO, MG) and Southeastern (SE) states (PR, RS, SP).

\begin{tabular}{|c|c|c|c|c|c|c|c|c|c|c|c|}
\hline \multirow[b]{2}{*}{ Fungicide $^{a}$} & \multirow[b]{2}{*}{ Region } & \multicolumn{5}{|c|}{ SBR control (\%) } & \multicolumn{5}{|c|}{ Yield response $\left(\mathrm{kg} \mathrm{ha}^{-1}\right)$} \\
\hline & & $k^{\mathbf{b}}$ & $\bar{C}$ & $\mathrm{CI}_{\mathrm{L}}{ }^{\mathrm{c}}$ & $\mathrm{CI}_{\mathrm{U}}^{\mathrm{c}}$ & P-value & $k^{\mathrm{b}}$ & $\bar{D}$ & $\mathrm{CI}_{\mathrm{L}}^{\mathrm{c}}$ & $\mathrm{CI}_{\mathrm{U}}^{\mathrm{c}}$ & P-value \\
\hline \multirow[t]{2}{*}{ AZOX + BENZ } & NW & 104 & 72.4 & 68.8 & 75.6 & 0.7748 & 104 & 894.3 & 805.9 & 982.7 & 0.4884 \\
\hline & SE & 40 & 73.4 & 61.8 & 81.4 & & 41 & 953.3 & 698.0 & 1208.6 & \\
\hline \multirow{2}{*}{ BIXF+TFLX+PROT } & NW & 88 & 74.5 & 71.7 & 77.4 & 0.0047 & 88 & 1032.7 & 940.1 & 1125.3 & 0.0987 \\
\hline & SE & 27 & 81.9 & 74.5 & 87.1 & & 28 & 1182.9 & 911.9 & 1453.8 & \\
\hline \multirow[t]{2}{*}{ PICO + BENZ } & NW & 87 & 73.8 & 70.4 & 76.7 & 0.8727 & 88 & $\begin{array}{c}1009 \\
8\end{array}$ & 922.4 & 1097.3 & 0.6678 \\
\hline & SE & 29 & 74.2 & 63.4 & 81.9 & & 30 & 973.2 & 718.5 & 1227.9 & \\
\hline \multirow[t]{2}{*}{ PICO + CYPR } & NW & 122 & 52.6 & 48.9 & 56.0 & $<0.0001$ & 126 & 554.8 & 497.8 & 611.7 & 0.0035 \\
\hline & SE & 47 & 64.5 & 55.8 & 71.5 & & 49 & 714.5 & 550.4 & 878.6 & \\
\hline \multirow[t]{2}{*}{ PICO + TEBU } & NW & 105 & 63.1 & 59.5 & 66.4 & 0.0015 & 108 & 645.6 & 579.3 & 711.9 & 0.0398 \\
\hline & $\mathrm{SE}$ & 44 & 72.4 & 63.7 & 79.0 & & 46 & 775.5 & 585.4 & 965.7 & \\
\hline \multirow[t]{2}{*}{ PYRA+EPOX+FLUX } & NW & 88 & 71.4 & 68.1 & 74.2 & 0.4135 & 88 & 967.0 & 878.9 & 1055.0 & 0.9038 \\
\hline & SE & 27 & 73.8 & 63.9 & 81.0 & & 28 & 977.4 & 719.9 & 1234.9 & \\
\hline \multirow[t]{2}{*}{ TFLX + CYPR } & NW & 106 & 53.7 & 49.7 & 57.3 & $<0.0001$ & 107 & 593.7 & 537.1 & 650.4 & 0.0008 \\
\hline & SE & 37 & 67.6 & 58.6 & 74.6 & & 39 & 776.0 & 612.5 & 939.6 & \\
\hline \multirow[t]{2}{*}{ TFLX + PROT } & NW & 121 & 68.6 & 65.3 & 71.7 & $<0.0001$ & 121 & 832.3 & 760.1 & 904.4 & 0.0034 \\
\hline & SE & 45 & 79.3 & 72.0 & 84.7 & & 48 & 1035.2 & 827.1 & 1243.3 & \\
\hline
\end{tabular}

${ }^{a}$ See Table 1 for complete information of the evaluated fungicides;

${ }^{\mathrm{b}}$ Number of trials that each fungicide was evaluated;

${ }^{c}$ Upper $\left(\mathbf{C I}_{\mathrm{U}}\right)$ and lower $\left(\mathbf{C I}_{\mathrm{L}}\right)$ limits of the $95 \%$ confidence interval around $\bar{C}$ and $\bar{D}$. 